University of Louisville

ThinkIR: The University of Louisville's Institutional Repository

Electronic Theses and Dissertations

1938

\title{
The effect of carbon pigments on drying of linseed oil.
}

H. A. Bennett

University of Louisville

Follow this and additional works at: https://ir.library.louisville.edu/etd

Part of the Chemical Engineering Commons

\section{Recommended Citation}

Bennett, H. A., "The effect of carbon pigments on drying of linseed oil." (1938). Electronic Theses and Dissertations. Paper 1665.

https://doi.org/10.18297/etd/1665

This Master's Thesis is brought to you for free and open access by ThinkIR: The University of Louisville's Institutional Repository. It has been accepted for inclusion in Electronic Theses and Dissertations by an authorized administrator of ThinkIR: The University of Louisville's Institutional Repository. This title appears here courtesy of the author, who has retained all other copyrights. For more information, please contact thinkir@louisville.edu. 
UnTVERSITY OF LOULSVIDLs

The irfeot of Carbon PIgaents on Drying of IIngeed 011

A Dissertation

Sulmitted to the Faculty

of the Greduate sohool

In Partial Fulfiliment of the

Requiremente for the Degree of

Naster of Cheriloal Inginearing

Department of Chendcal Inginearing

\author{
By \\ $\mu x e^{N}$ \\ B. A. Bennett Jr. \\ III
}


The refect of Carbon Plgoents

On Drying of Inseed o1I

Directom Dr. R. C. Bmot.

Approved by Reading Commt tee:

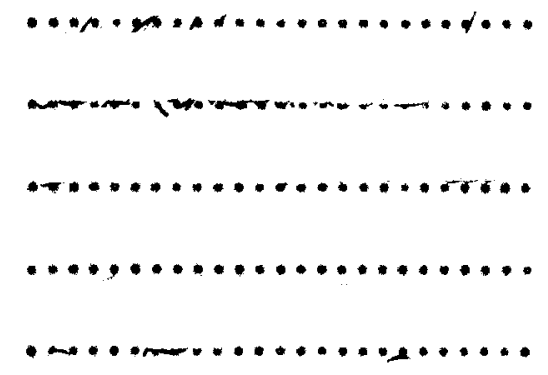


TABLE OF CONPGNSS

List of Tables

PaEO

List of Figures

Acknowl edgenent

Chapter I Introduction

Chaptor II Thoorotionl

Chapter III Naterfals, Apnaratus, and Procoodure

11

Chapter IV Date and Results

24

Chapter $\nabla$ summary

68

B1bliography

7 


\section{LIST OF TRBLES}

Table No.

Page

1 List of Linseod oll - Drier - Plgment Mixtures studied

26

2 Drylng Data for Lineed 011 containing 1 Gram

Lead and 3.6 Grams Carbon Black por 200 Grame ofl 17

3 Dryins Date for Linseed ofl containing 1.5 Grams

Load and 3.E Grams Carbon Black por 100 Gram 011

19

4

Drying Data for Linseed 011 Containing 2 Grams Lead and 3.6 Grame Carbon Black por 100 Grams 011

21

5 Dryin Dete for Linseed 011 Containing $1 \mathrm{Gram}$ Laed and 7 Grams Carban Black per 100 Grans of 011

23

6 Drying Data for Linseed oll containing 1.6 orsms Lead and 7 Grams Carbon Bleok per 100 Grems 012

26

Drying Data for Linseed oll containing 2 Grams Lead and 7 aram Carbon Blaok per $100 \mathrm{Grams}$ OLI

8 Drying Inta for Linoeed ofl containing 1 Gram Load and 10 cram Bemebleok par 100 orams 011

9 Dryine Data for Lineeed 011 coatalning $1 \mathrm{Gran}$ Lead and 20 Grama Bono bleok por 100 Grams ofl

10 Drying Date for Linseed 011 Containing 2 Grams Lead and 10 Grams Bone blaok per 100 Grame 012

11 Drylng Data for Lineed 011 containing 2 Grams Lead and 20 grams Bone black per 100 Grame ofl

Dryinf Data for Linseed of I containing 1 Gran Lead and 7 Grums lamp bleok per 100 Grems of 1

Drying lata for Linseed oll containing 1 Gran Lead and 14 Grans Lamp black per 100 Grams 011

14 Drying Data for linseed onl contalning 2 crams Load and 7 Grams lamp black por 100 Grems oll

15 Drying Data for Linseed 011 cantaining 2 Grams Lead and 14 Grams Lamp Blaok per 100 Grams os 1

26 Drylng Data for Linseed oil contalning $1 \mathrm{Gram}$ Lead and 14 Grams Graphito for 100 Grams ofl 
17 Drying Date for Linseed 011 Containing 2 Gram Load and 14 Grams Graphite per 100 Grans $0: 1$

18 Irying Data for Linsood OII Containing 1 Gram Loud and 28 Grane Graphito por 100 Grans 011

19 Drying Data for Lineed oll containing 2 Grase Load and 28 eranis Graphito per 100 Grams ofl

20. Drylng Ieta for Linseed 011 Containing 0.025 Grase cobalt and 3.5 Grams Carbon Black per 100 grans 011

21 Drying Dat for Linseed 011 contalning 0.025 Grams cobalt and 7 ar carbon Black per 100 orams of 1

22 Drying Data for Linseed oll contalning 0.04 Grams cobalt and 3.6 Grans Carbon Bisak per 100 Grams 011

23 Urying Data for Lineeed oil contalning 0.04 Gra Cobalt and 7 Grams Carbon Blaak per 100 Grams 011

24 Drying Data for Linsed oll containing Leud Drier with No Plemont

26 Dryine lata for Lineed oil containing cobalt Drier in No Pigment 
LIST O PIOUEES

Plegre Ho.

Page No.

1 Apparatus for raking Paint Films

13

2 Drying Rate of Linseod ofl Containing $1.0 \mathrm{gm}$. of lead per $200 \mathrm{gn}$. OSI

18.

3 Drylne Rate of Linseed 011 containing $1.5 \mathrm{gm}$, of Laad por $100 \mathrm{gm}$. of oll

20

4 Drying tat of Lineed oll containing $2.0 \mathrm{gm}$. of Loud por $100 \mathrm{gm}$. of 011

22

5 Irylng tete of Lineed oll containing $1.0 \mathrm{gm}$ of Lead per $100 \mathrm{gm}$, of $0 \mathrm{I}$

6 Drylns fiate of linseed 011 containing $1.5 \mathrm{gm}$. of load por $100 \mathrm{gme}$ of $0 \mathrm{Ll}$

Drying Rate of lineeed 011 contelning $2.0 \mathrm{gm}$. of lead per $100 \mathrm{gm}$. of 011

8 Drylng Rate of Linseed 011 containing $1.0 \mathrm{gm}$. of lead par $100 \mathrm{gm}$ of ol 1

Drying fete of Ilnsed oll contalning $1.0 \mathrm{gm}$ of leed per $100 \mathrm{gm}$. of 012

10 Drying to of Lineeed 011 containing $2.0 \mathrm{gm}$. of lead per $100 \mathrm{gm}$. of 011

11 Drying tate of Linseed oll containing $2.0 \mathrm{gm}$. of Lead por $100 \mathrm{gm}$. of $0 \mathrm{il}$

12 Drying Fate of Linseed oll Containing $1.0 \mathrm{gm}$. of Load por $100 \mathrm{gm}$. of 011

13 Irying pato of linsed oll containing $1.0 \mathrm{gm}$ of load per $100 \mathrm{gm}$. of $\mathrm{OLI}$

14 Drying kato of Linseed OLI Containing $2.0 \mathrm{gm}$. of Lead per $100 \mathrm{Em}$. of $0 \mathrm{LI}$

16 Drying Fato of hinseed 011 containing $2.0 \mathrm{gm}$. of Leed per $100 \mathrm{gm}$. of 011

16 Drying fate of Linseed 011 Contining $1.0 \mathrm{gm}$. of Lead per $100 \mathrm{gth}$. of 021

17 Drylng liate of Lineed 011 containing $2.0 \mathrm{gn}$. of Lead per $100 \mathrm{gm}$. of 011 
Drylng the of Linseed 011 contalnging $1.0 \mathrm{gm}$. of Lead per $200 \mathrm{gm}$. of 011

19 Drying Rate of Linseed oll Containing $2.0 \mathrm{gm}$. of lead per $100 \mathrm{gm}$. of 011

20 Dryine Fate of Linseod ol contaluing .025 gm. of Cobelt per $100 \mathrm{gm}$. of 011

21 Drying kete of Linseed oll Contalnting .025 gm. of Cobalt per 100 of all

Drying tate of Linseed oll coutalining .04 ge. of Cobalt per $100 \mathrm{gm}$ of 011

Drying tate of Linseed 011 conteining $.04 \mathrm{gm}$. of Cobelt per $100 \mathrm{gm}$. of ofl 
ACKMOTLEDQELE WT

The author wishes to acknowledge his

appreolation for the ald given by Dr. H. C. Ernot, who direoted his resear oh. 
CHAPIIR I

IMHODJCTION 




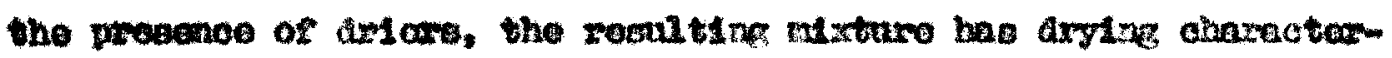

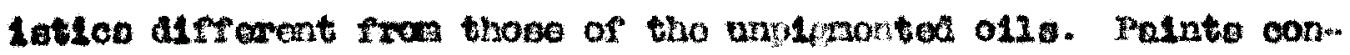

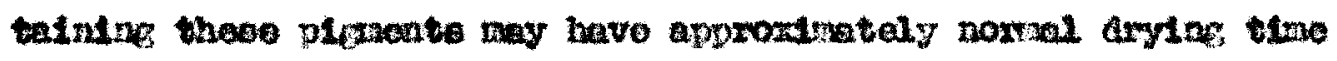
then froahly made, bat aftes aftac will havo an undulg long Arying

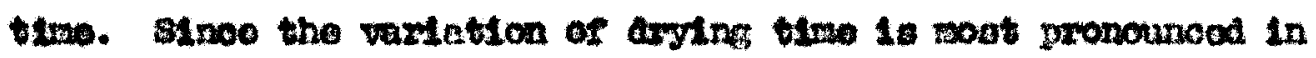

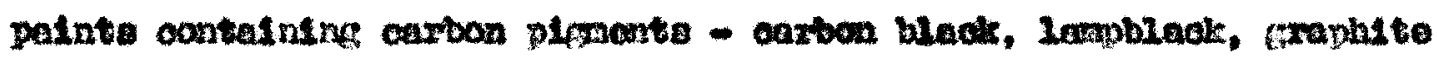
and banoblack -, thore havo boen nelocted ror this otudy.

Litlie imformation is avaliaule oonocming the orfect of

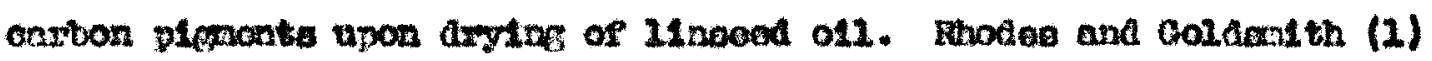

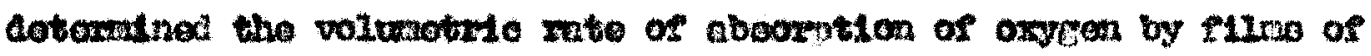
carbout black paint. Molr malta gave no information on the orfoct of acting of tho patint.

The adeorption of triers by black ploments in mphtha

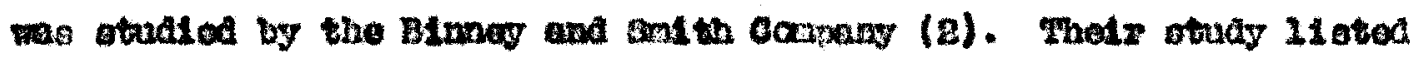

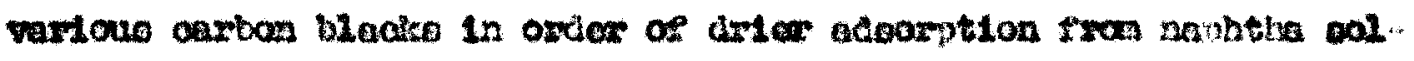

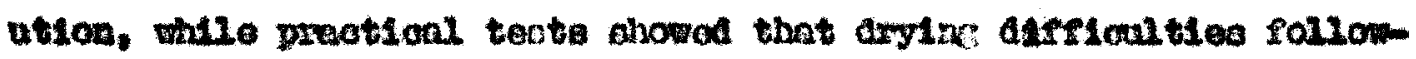

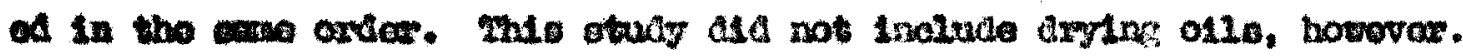

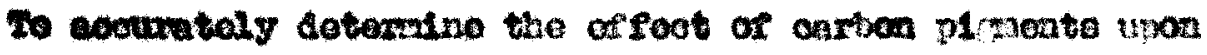


Silso nust bo obtalnod. Tho arying chnmotamatice will bo cotorilsok

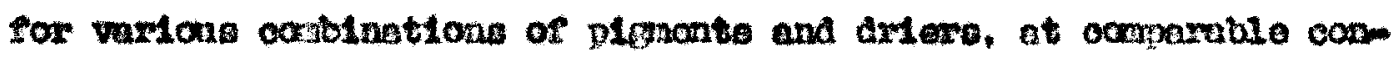
Ations of 1Ldt, tomereture, huldts, and min maknow. 
CHAPTIRR II

THEOREICAT 
The change resulting when a veretable oll, such as 11 nseed 011, Ia sproad in a thin film and exposed to fir is actually an oxidation and polymerization of the oll, although the change is comonly torned drying.

The following description of the drying of Iinseed ofl is due to Long and assoclates (3) and Rhelneck (4). Tho ohiof arying constituent of 11 nseed oll is Iinolente actd, which has the following structure:

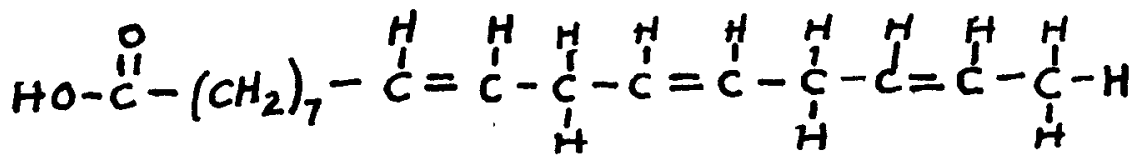

The arying process is primarily a roaction at the points of unsaturation, that 1s, at the location of double valence bonde on the stmictural formule indlcatod. In the first step of the process, oxygen 18 absorbed as a poroxich



Thls perozide formation $1 \mathrm{~s}$ unstable and exists only up to the point where the oll filn is tacky. Once the film 1 s ary to touch, polymerlzation, and a renmangemont of the peroxide compound occur:

Durine the latter part of the arylng period volatile products are elven off by the oll film. Th1s $108 \mathrm{~s}$ of roletile products 1s explained by reaction of the oxidized linolente acid with moisture, present ofther in the oll or in the alr: 
L8 Ilnseed oll arles alowly by itsalf, when flowed out in a thin flin, materials known as arlers are added to apeed up the drying process. These matemels act catalgtlcally and are added in mall quant1t1es to the oll. Cobalt, lead, and manganese conpounds are the common driers; their activity as catalysts of the reaction of the AryIng of ofle depends npon their abtlity to form two or more compounds wth oxygen, wich differ from each other in the amount of oxygen with which the same weight of metal 18 combined. To make activo catalyzers, or Ariers, these ccmpounds with oxygen met be unstable, that is, that they will pass readily from one lage of oxddation to another. These catalyzers form the compounds of largeat oxygen content whan thes are at the surface of the oll film in contact of th the oxygen of the air. Later, due to the contimous movement of the particles, the h1gh oxygen bodies owe in contact with the unoxdized oit thd give up their ozvgen, thus quiakening the reaction. The drier metal to iro usually added as IInoleates, naphthenates, or almilar organte compounds, so that the arier may be readily alspersed in the oll.

The arying of an oll can be represented Graphioally by a curve showlng increase in volght of oll plotted egainst time. A typ10al ourve show a elor rate of increase in welght of oll just after the arying begins; this period in the drying 10 called the Intuction pertod. Inmodiately following the induetion period, the curro goes sharply uprand at a constent slope, indicating a perlod of constant rate of increase in weight. The constant rate period continues until a cortain stage in arying is reached. The rate of increase in weight then falls off, but the welght increases alowiy unt1l a maximam is reached. 
Lose of volat1le products causes the curve to drop after the maxtman is reached.

Craphical representation gives a convenient mothod of comparing the dxying of different mixtures of 011, arler, and plgment. 
GIAPTER III

MATZRTATS; APPARATUS, AND PROC BADURE 
The ramples 1nvestigated were mixtures of 11 neeed oll with efther carbon black, lamblack, craphite, or bonoblack, with olther load or cobelt Nuodex used as the drier. Tho pigment and o1l vere welghed and the Nuodex drier, which is a solution of a metal naphthenate in naphtha, adied with a eraduated pi at. Samples of approximately ono-half pint were prepared in each caso, and eround in a amall pebble mill.

The flim were prepared by first painting a thiak coating of the semple on a flat labs plate, nine by twelve centimoters in size. As indicatod in Flgure 1, a film of constant thicimoss mas obtained by drawing across the flat glasa plate a doctor blade held fimly against the two thicknoss gage otrlps. The f1lmo were veighed at varylng intervals on an analytical belance, and the fncrease in walght noted.

The fllms were exposed to the light fram a 100 watt General Hectric daylight type lamp, which was 31 inches ebove the plane of the deak top. The terperature was held at 80 dogroes Fahrenhelt for all testa. The average relative humidity during the testo made on the freahly made anples and on the samplos after 4 weoks aglne was 30 percent; during the tests made on the somples after 8 woeks aglag, the relative humidity was 45 percent. 
Figure 1.

Apparatus for Making

Paint Films.




CHAPIER IV

DATA AND RESULTS 
To express the increase in voifht of the films on a comparable basis, the weight of ofl in the film was used as the basis.

The wolght of oil in the sample obtained by multiplying the peight of aemple by the percent oil in the sample. The percent oll was known from the preparation of the ample; for example, 98 grams of 011,1 gram of pignent, and 1 gram of drier gave a mixture of 98 percent oll content. Weight of oll dividod. by increase in welght gave percent incrase in welght of ofl, from which the drylng curves wore plotted.

Table 1 showe the composition of the various mixtures of IInseed oll - arier - plopent mixtures studied in this investigation. 
Table 1

List of I1nceod o1l - duler - plmont mixtures studied.




Table 2

Drying date for IInsed oll contalmine 1 crem 1 oad and 3.5 grand carbon black per 100 grame o11. (Pexoent 011, 03.0)

Exoghts mace anmio

W. eamplo, 0.2157 $\mathrm{B}$. Wt. ofl. 0,8002 $\mathrm{E}$.

Time, Inoroase

Bour:
$\%$ 2xoreabe In walght of oll

\section{4reoke sotng}

B. moles aging

Tt. eample, 0.2823 g. Wt. buxple, 0.2445 g. Wt. 011. 0.8160 g. Nt. oll, a.2275 E. exrone

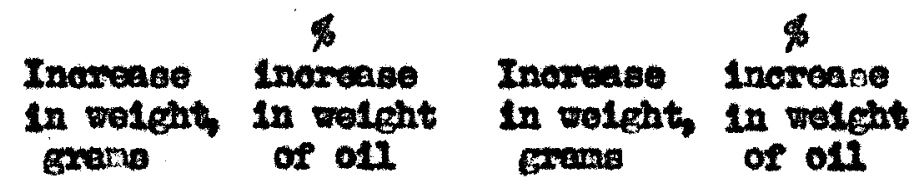

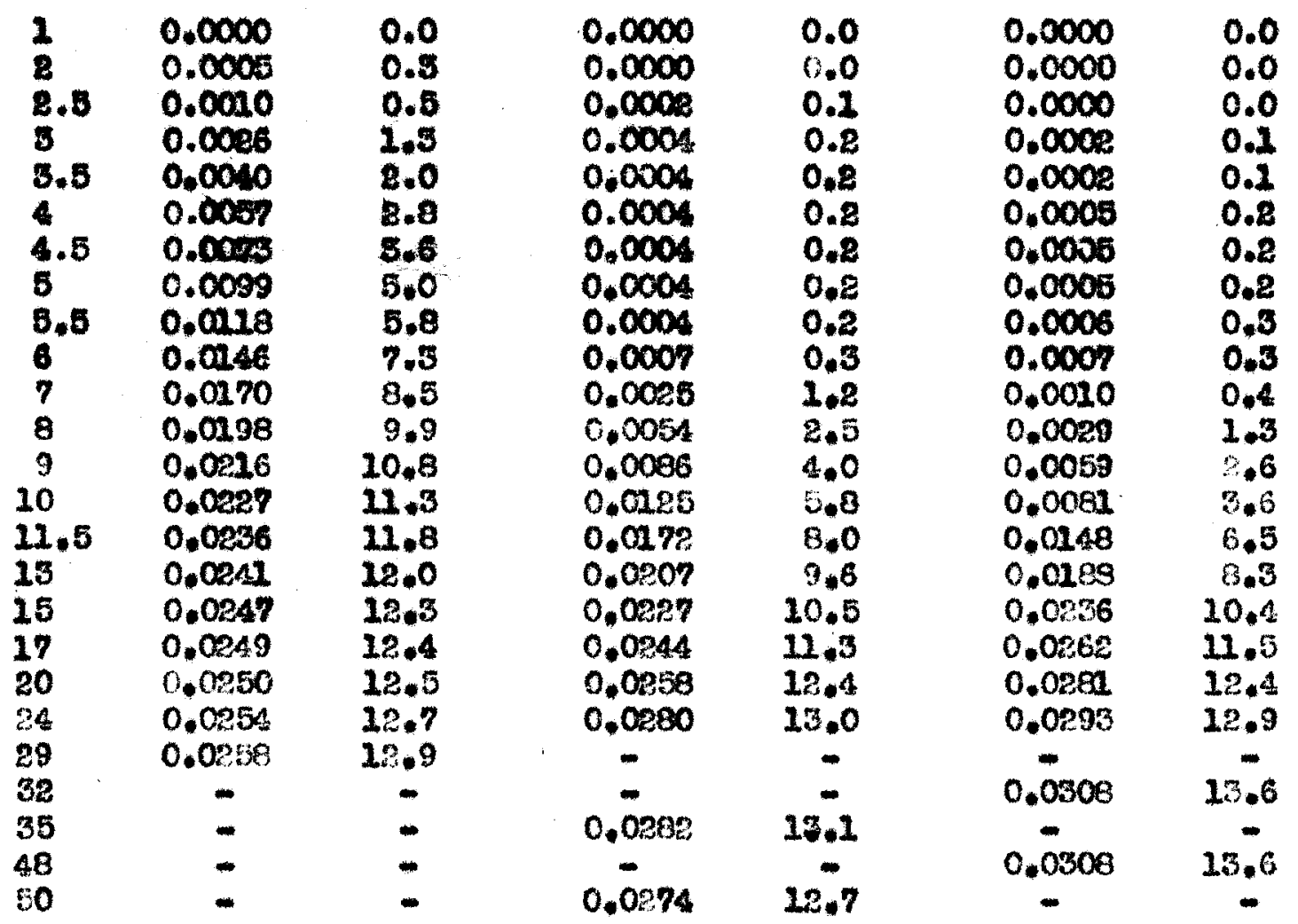




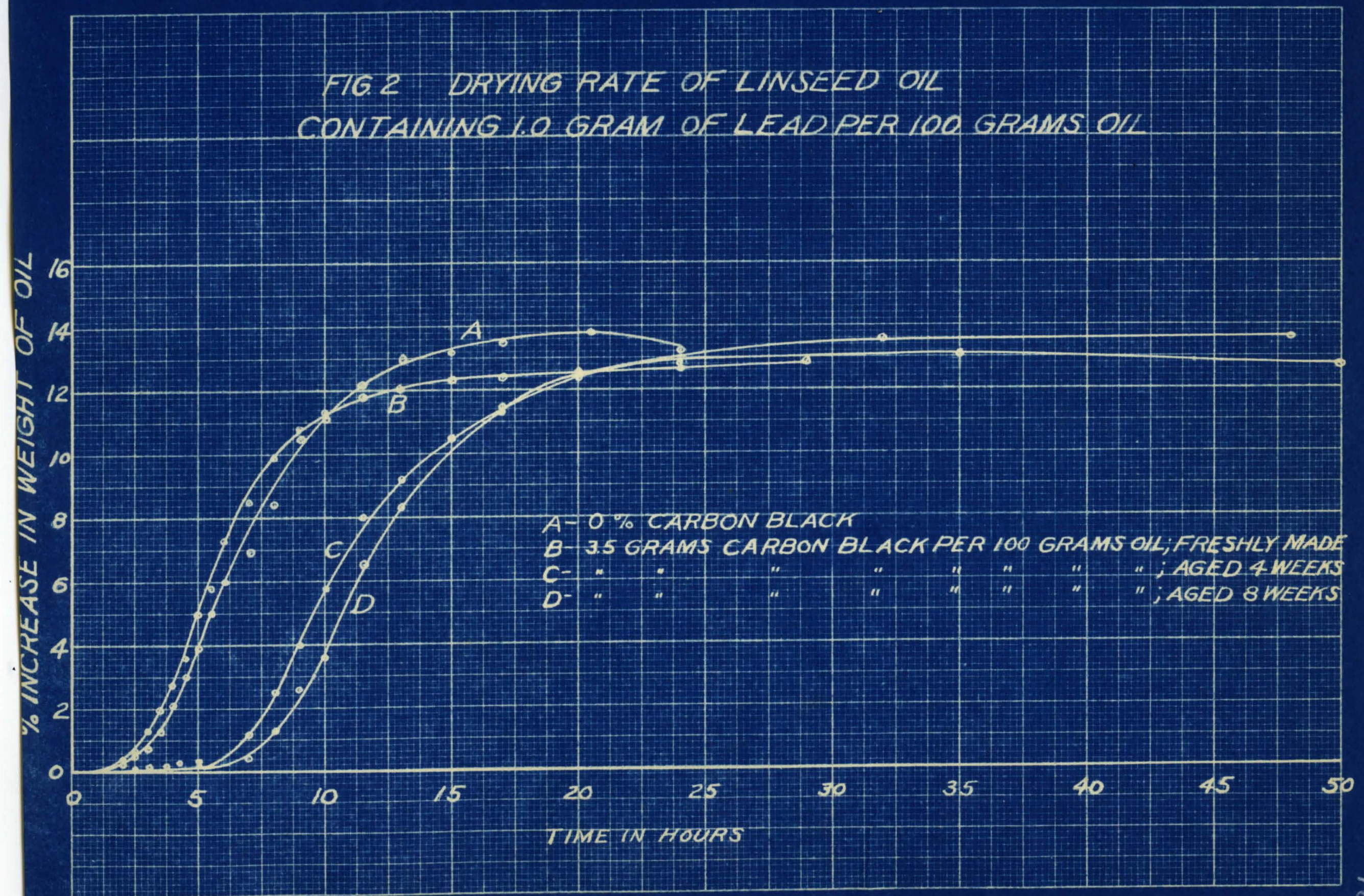


Table 3

Dryine data for 1 insed o11 containin 2.5 oram 2 ead and 3.5 grum carbon black bor 100 (rens oll. (Poncost $011,91,4)$

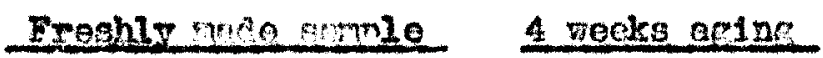

B weoks acine

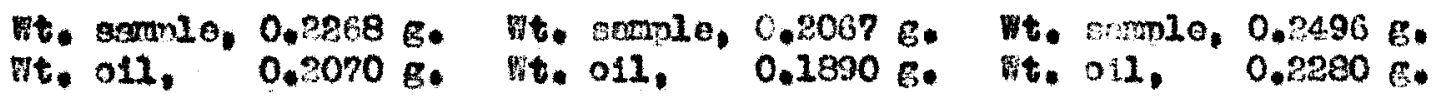




Table 4

Drying dete for lineece oll containing 2 crans lea and 3.5 grume crobon black per 100 grams o1l. (Percent 011, 89.4)

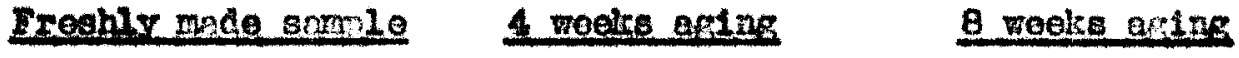

Wt. samplo, 0.2461 g. Wt. smaplo, $0.1785 \mathrm{~g}$. Wt. samplo, $0.2546 \mathrm{~g}$



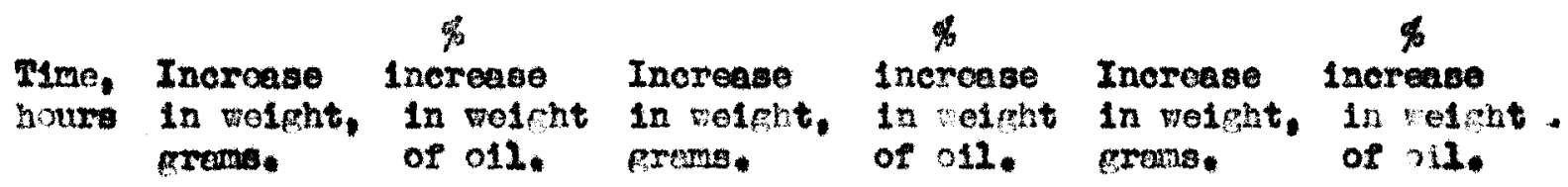

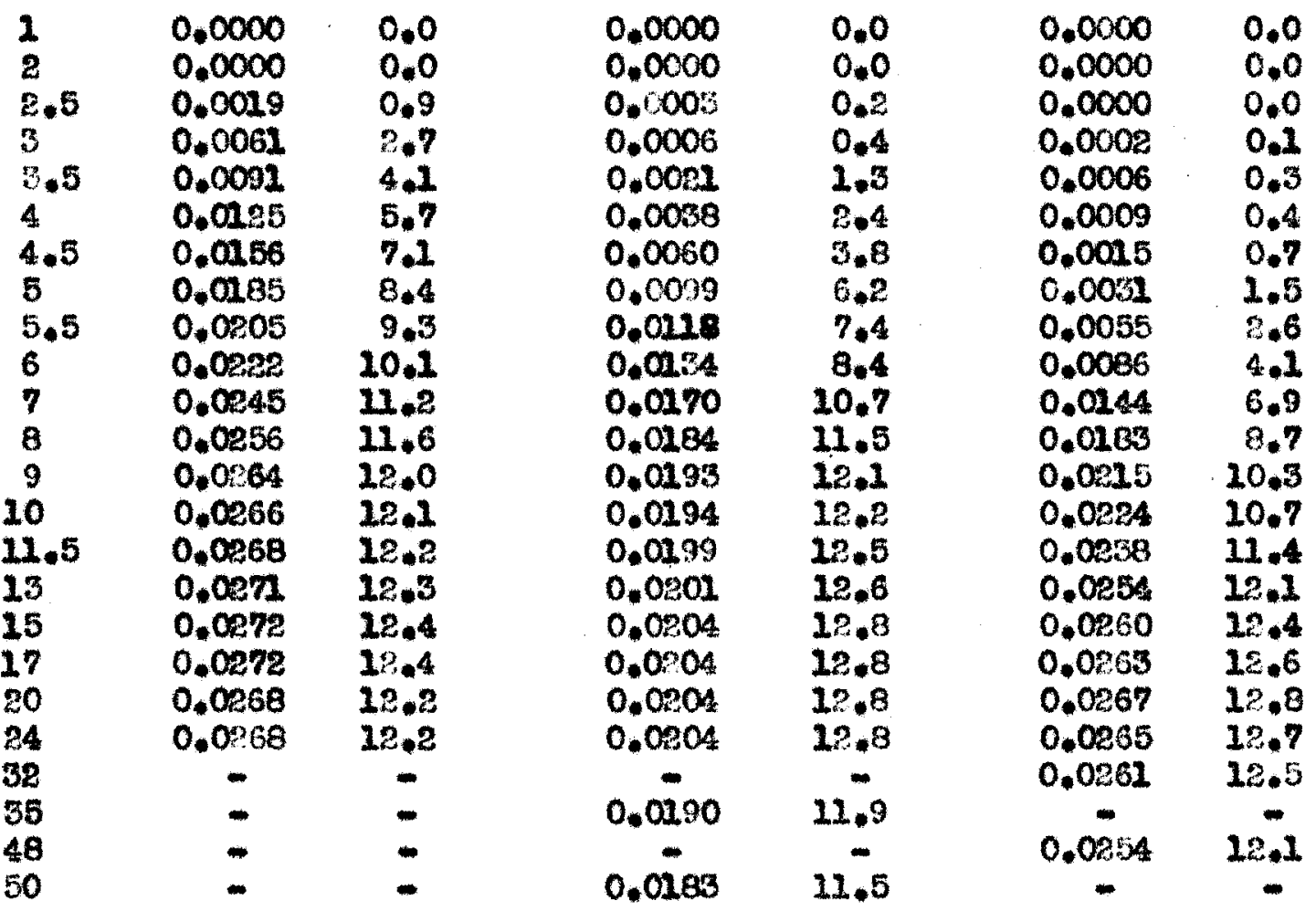


Table 5

Drying data for 11 nseed oll contalning 1 gram lead and 7 was carbon black por 100 erems 011. (Percent oil, 89.9)

\section{Treghy made sample}

vt. armile, $0.2765 \mathrm{~B}$. t. oll. 0,2484 $\mathrm{E}$.
4 meoles oring

14. samplo, 0.2816.8. it. 011. 0,2528

Q moaks acing

T. samp $0,0.2483 \mathrm{~g}$. Wt. 011, 0.2234 E.

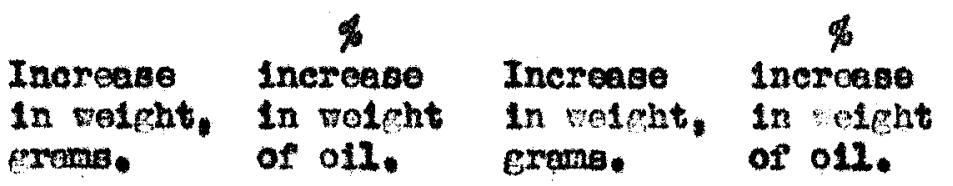

0.0000

0.0000

0,0005

0,0005

0,0005

0,0005

0,0005

0,0007

0,0007

0,0007

0,0007

0,0010

0.0010

0.0010

0.0025

0.0038

0.0215

0.0171

0,0226

0.0288

11. 4

-

0.0521

$-$

0.0305
0.0

0.0

0.2

C, 2

0.2

0.2

0.2

0.3

0.3

0,3

0.3.

0.4

0.4

0.4

1.0

1.5

4.5

6.8

9.0

-

15.3

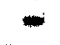

2.1
0.0000

0.0000

0.0000

0.0000

0.0003

0.0003

0.0005

0.0003

0.0003

0.0003

0.0003

0.0003

0.0008

0.0021

0.0014

0.0034

0.0095

0.0150

0.0723

0.0259

0.0

0.0

0.0

0.0

0.2

0.1

0.1

0.1

0.1

0.1

0.1

0.1

0.4

0.5

0.6

1.5

4.3

7.1

10.0

11.6

0.0280

$-$

12.5

0.0290

$18 \%$

50 
Table 6

Drylag data for lingeod ofl contaluing 1.5 groms $10 a d$ and 7 rems earbon bladk per 100 grams o11. (Pereent 011, 03,3)

Ireshly agde annie 4 beoka aging

7. semple, 0.2892 B. th. o11, 0.2112 E. Time, Inomease increase
hours in volght, in woight
grams. $2 \quad 0.0000 \quad 0.0$ $2 \quad 0.0003 \quad 0.1$ 2.50 .00040 .2 $3 \quad 0,0012 \quad 0.6$

$3.5 \quad 0.0020 \quad 0.9$

$4 \quad 0,0031 \quad 1.5$

$4.5 \quad 0,0046 \quad 2.2$

$5 \quad 0.0073 \quad 3.5$

$5.5 \quad 0.0096 \quad 4.6$

$6 \quad 0.0127 \quad 6.1$

$7 \quad 0.0159 \quad 7.6$

$80.0294 \quad 9.2$

$\begin{array}{lll}9 & 0.0208 & 9.9\end{array}$

$10 \quad 0.022 \quad 10.5$

$11.5 \quad 0.0034 \quad 11.1$

$13 \quad 0.0241 \quad 11.5$

15

17

20

2,4

20

$3 \%$

35

48

50
$0.0249 \quad 11.8$

$0.0249 \quad 11.9$

$0.0049 \quad 11.8$

$0.025, \quad 12.1$

$0.0259 \quad 12.3$

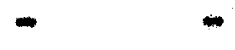

Ft. sample, 0.2451 $\mathrm{g}$

Vit. 011.

0.2146 E*

Increase Increase

in relght, in metrit

erene.
8 rooks andng

t. sermie, 0,1858 B. vt. 0L1. 0,1640 g.

Increase Increase

In velght, in velght crems, of 011 .






\section{FIG S DRYING RATE OF LINSEED OL}

CONTALNING IS GRAMS LEAD RER 100 GRAMS OM
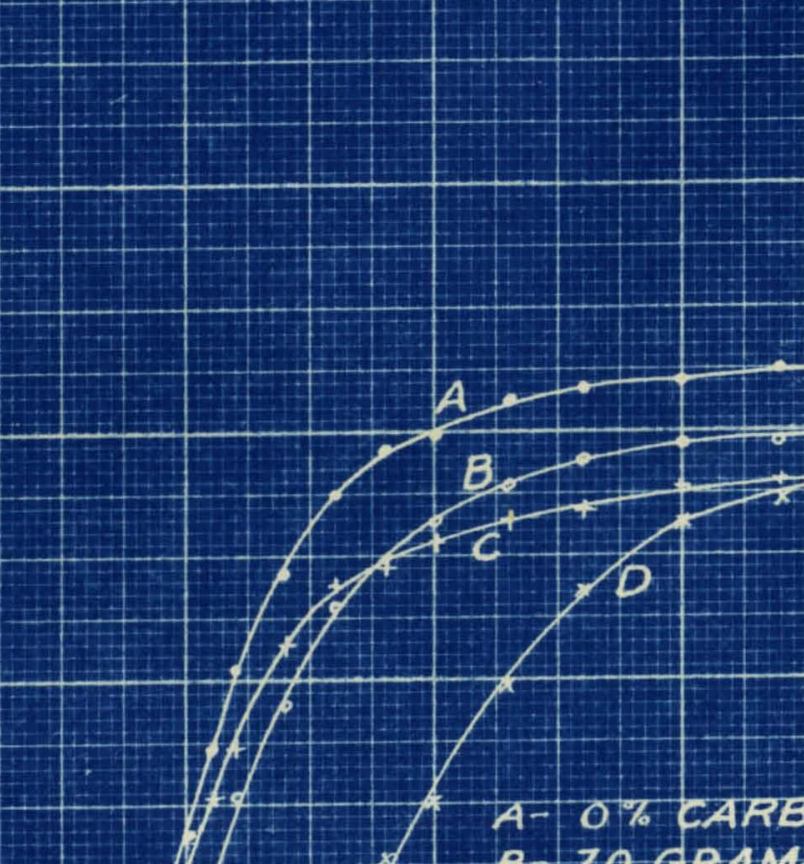

A- $0 \%$ CAREON EL ACK

B- 70 CRAMS CARBON BLACK PER IOD GRAMS OH; FRESHLY MADE

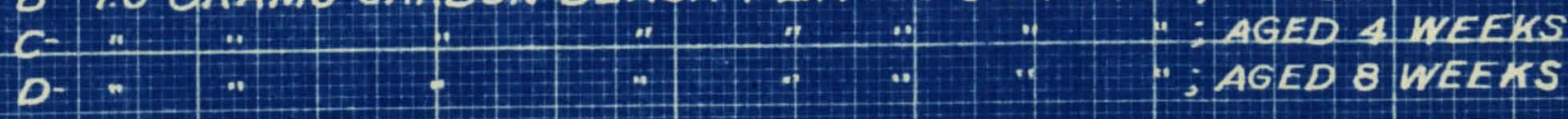

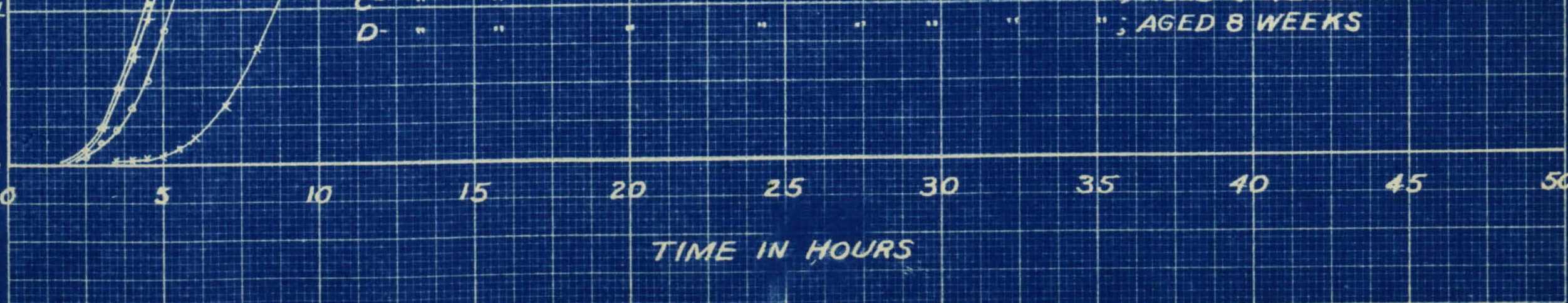


Table 7

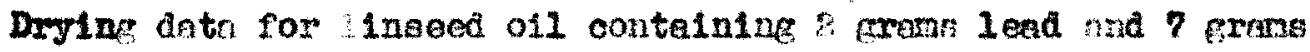
c rbon black per 100 crams oll, (Pereent 011, 86.8)

rachly made eample

A weeks exting

B reokin aging

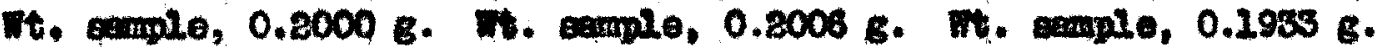
Tt. 011, 0.1738 G. Tt. o11, $0.1740 \mathrm{~g}$. Tt. 011, $0.1678 \mathrm{~g}$.

\begin{tabular}{|c|c|c|c|c|c|c|}
\hline $\begin{array}{l}\text { Ptmo, } \\
\text { Daturs }\end{array}$ &  & $\begin{array}{l}\text { increaso } \\
\text { in whe } \\
\text { of oll. }\end{array}$ & $\begin{array}{l}\text { Inomease } \\
\text { In velght, } \\
\text { Eums. }\end{array}$ & $\begin{array}{l}\text { Inoreabo } \\
\text { in wotght } \\
\text { of obl. }\end{array}$ & $\begin{array}{l}\text { Tnoreabo } \\
\text { in rolght } \\
\text { gxams. }\end{array}$ & $\begin{array}{l}\text { Inox } \\
\text { In } \\
\text { of }\end{array}$ \\
\hline 2 & 0.0000 & 0.0 & 0.0 & 0.0 & 0.0000 & \\
\hline 2 & 0.0 .09 & 0.5 & 0.0000 & 0.0 & 0.000 & \\
\hline 2,5 & 0,0023 & 1.5 & 0.0002 & 0.1 & 0,000 & \\
\hline 3 & 0.0050 & $m .9$ & 0.0114 & 0.8 & 0.0010 & \\
\hline 3.5 & 0.0071 & 4.1 & 0.000 & 1.7 & 0.000 & \\
\hline 4 & 0,0093 & 5.4 & 0.005 & 2.9 & 0.0002 & \\
\hline 4.5 & C.0112 & 6.5 & 0.0077 & 4.4 & 0.0002 & \\
\hline 5 & 0.0124 & 7.7 & 0.0205 & 6.0 & 0.0004 & \\
\hline 5.5 & 0.0240 & e.5 & $0.02,00$ & 8.9 & 0.0006 & \\
\hline 6 & 0,0264 & 8.5 & 0.0127 & 7.9 & 0.0012 & \\
\hline 7 & 0.0179 & 10.3 & 0.160 & .5 & 0.0030 & \\
\hline e & $0.019 x$ & 11.1 & 0.0270 & 10.2 & 0.6004 & \\
\hline 0 & 0,0138 & $11 \cdot 4$ & 0.0185 & 10.6 & 0,0103 & \\
\hline 10 & 0,0201 & 12.6 & 0.0202 & 11.0 & 0.1225 & \\
\hline 11.5 & 0,0204 & 21.8 & 0.0194 & 11.1 & 0.0150 & \\
\hline 13 & 0.0200 & 12.0 & $c .0196$ & 11.3 & 0.0272 & \\
\hline 15 & 0,0200 & 12,0 & $\mathrm{C}, 0201$ & 11.5 & 0.0127 & \\
\hline 17 & 0.0207 & 11.9 & 0.0301 & 11.5 & 0.0192 & \\
\hline 20 & 0.0205 & 11.8 & 0.0202 & 21.6 & 0.0294 & \\
\hline 24 & 0.0205 & 11.8 & 0.0204 & 11.7 & 0.297 & \\
\hline 32 & - & - & - & - & 0.0200 & \\
\hline 35 & - & - & 0,0194 & 21.1 & - & \\
\hline 48 & - & - & - & " & 0.0197 & \\
\hline 50 & - & . & 0.0183 & 10.8 & - & \\
\hline
\end{tabular}




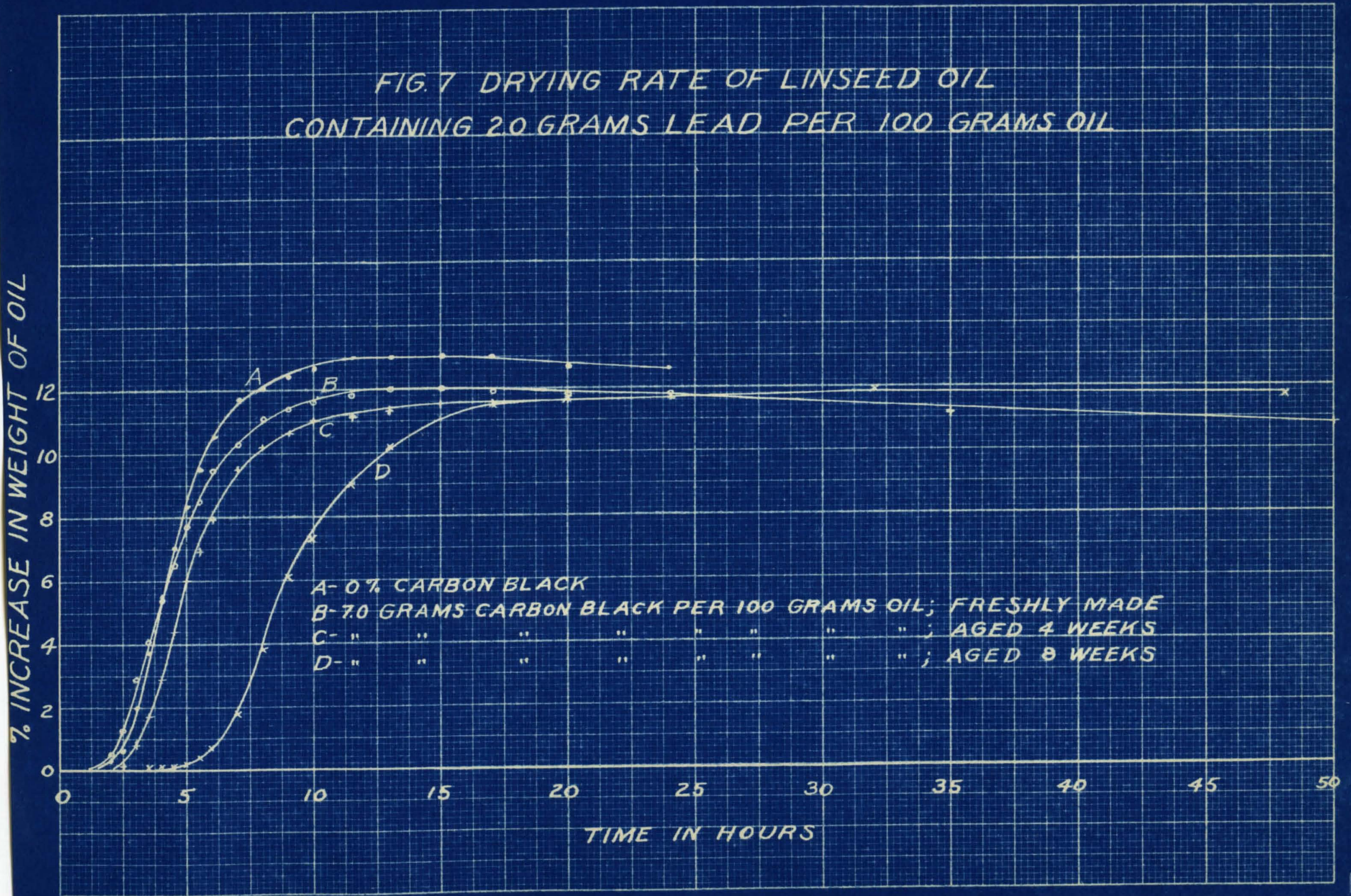


The drytng curvos for IInseed oll containing lead arler and carbon black, Heures $2,3,4,5,6$ and 7 , show that a freshly made carbon bleck paint has approxdmately the same arylng time as unplenented oll having the seme arler concentration. The length of the Induction period and the time for reachins a maxtman per cont Increase in watght of oll approximately the same in each case for freably made carbon black paint and unplgmented oll of equal arter concentration, although the maximum por cont increase in wolght of 011 of the unplomented sample we about one per oent greater than the corresponding inorease for the freshly made carbon black sample. The effect of aging mas to increase the time of the induction pertod in each cose. The alope of all the curves in the constant arying rate period, which Inriedately follows the induction period, wa approxImately the seme, showing there was no change of drylne rate during thls porlod. However, a decreasine constant rate period was notod with increase in age of the semple.

These curves all show that the drying time of a I1nseed oll lead dryer - carbon black mixture changes considerably with Increase In age of the mixture; and that the increase in drying tine is larger for mixtures of hlgher carbon black concontration. 
Table 8

Drying cata for linseed oll conteintse 1 pram lood and 10 erams boneblack par 100 grams o11. (Percent 011,87.6)

Eroghl r made aemnle

Wt. eample, $0.2900 \mathrm{E}$ $\mathrm{Wt}$, o11, $0.2540 \mathrm{BH}$

$\$$

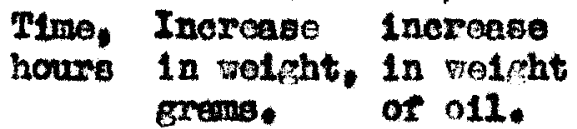

1

2

3

4

5

6

7

8

9

10

11.5

13

15

17

20

24

28

30

37

48

50

$\begin{array}{cc}0.0000 & 0.0 \\ 0.0002 & 0.1 \\ 0.0004 & 0.2 \\ 0.0004 & 0.2 \\ 0.0004 & 0.2 \\ 0.0004 & 0.2 \\ 0.0004 & 0.2 \\ 0.0004 & 0.2 \\ 0.0004 & 0.2 \\ 0.0009 & 0.4 \\ 0.0028 & 0.2 \\ 0.0036 & 1.4 \\ 0.0068 & 2.7 \\ 0.0204 & 4.1 \\ 0.0260 & 6.3 \\ 0.0238 & 9.1 \\ 0.0099 & 12.8 \\ - & - \\ - & - \\ 0.0343 & 13.9\end{array}$

4 nooke aging

t. sem 10, 0.2727 B.

it. o11.
8 weeks eging

Wt. aample, 0,2502 8. Wt. 011, 0,2194 E.

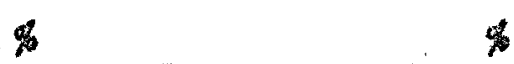

Increase increabe Inoreabe increabe in volght, in velght in veight, in velght Erems. of oll. crans. of o11.






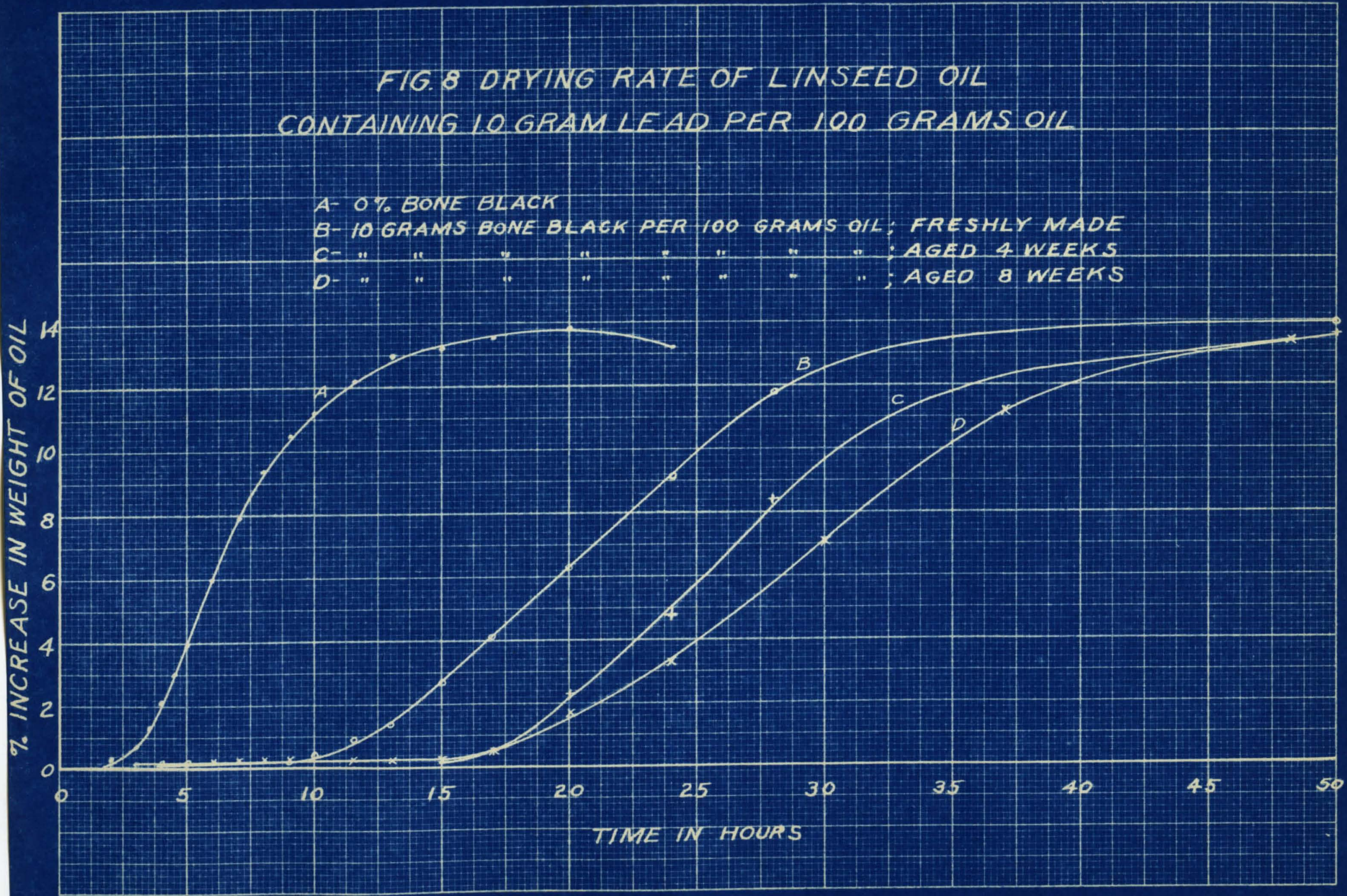


Table 9

Dryine date for 11 nsood oll containing 1 grm load end 20 grans bone black ner 100 grams oll.(Peavent 01., 80.5)

Proghtr made ramols

A reake apting



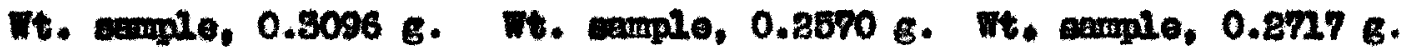

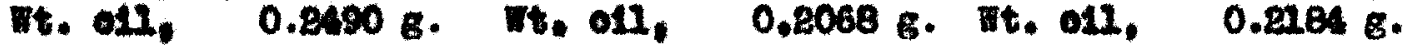

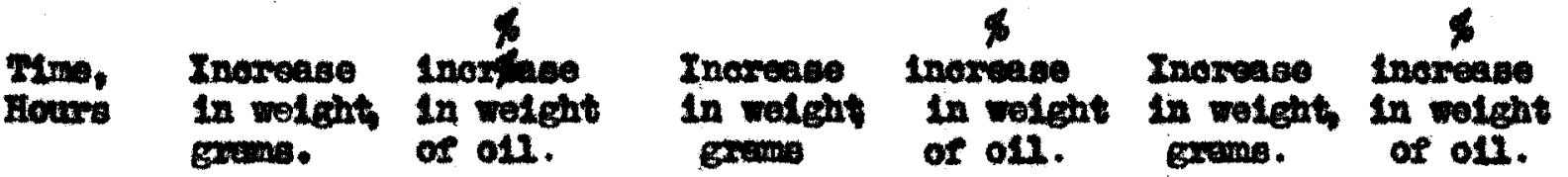

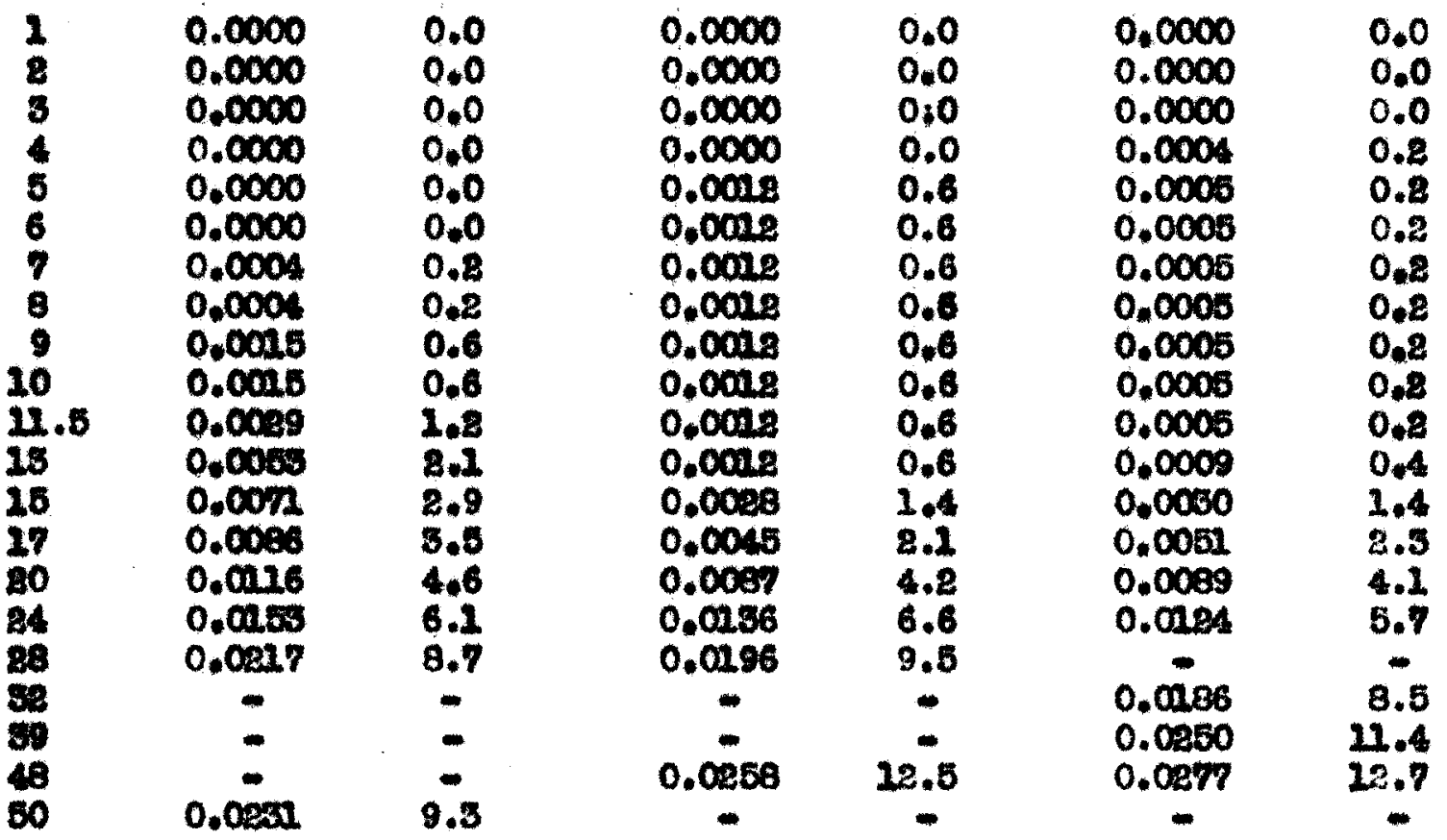




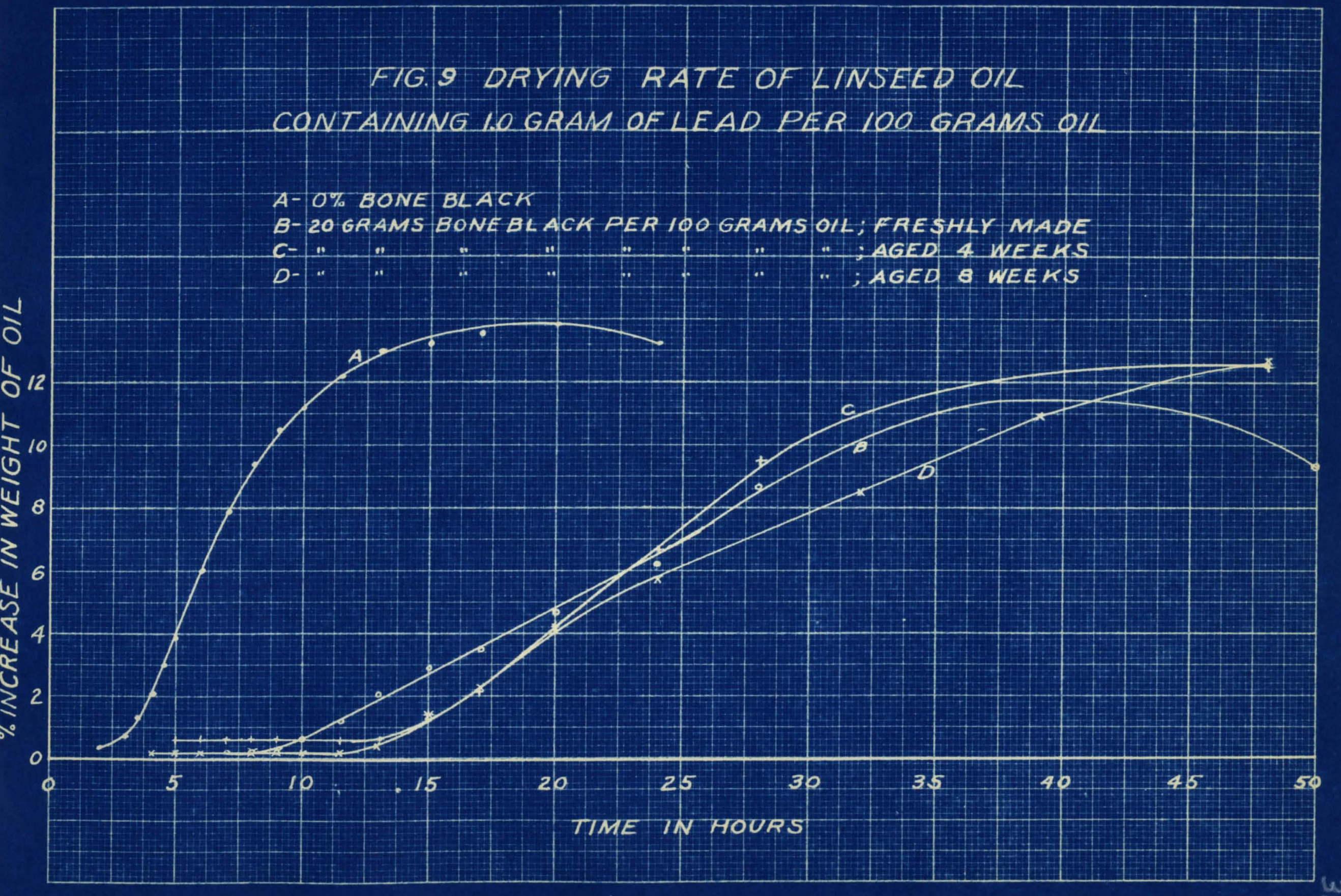


2ab1e 10

Drying date for 11 noeod oll containing 2 grams lead and 10 rams bone black per 100 grame o1l. (Pereent 011, 84.6)

Ereghly made sample

7t. ample, $0.2165 \mathrm{~g}$. Wt. 011, $0.1826 \mathrm{E}$.

Timo, Hours

$\begin{array}{ccc}1 & 0.0000 & 0.0 \\ 2 & 0.0000 & 0.0 \\ 3 & 0.0000 & 0.0 \\ 4 & 0.0004 & 0.2 \\ 5 & 0.0026 & 1.4 \\ 6 & 0.0065 & 3.6 \\ 7 & 0.0110 & 0.0 \\ 8 & 0.0149 & 8.2 \\ 9 & 0.0179 & 9.8 \\ 10 & 0.0194 & 10.6 \\ 11.5 & 0.0212 & 1.6 \\ 13 & 0.0227 & 12.5 \\ 15 & 0.0232 & 12.7 \\ 17 & 0.0231 & 12.7 \\ 80 & 0.0231 & 12.7 \\ 24 & 0.0281 & 12.7 \\ 28 & 0.0231 & 12.7 \\ 32 & - & - \\ 39 & - & - \\ 48 & 0.0217 & 11.9\end{array}$

4 reokg aging

8 rooks eging

Wt. aarmle, 0.2432 e. Wt. ample, $0.2547 \mathrm{E.}$ wt. 011, , $0.2053 \mathrm{~g}$. Wt. o1l, $0.2160 \mathrm{~g}$. Increase incrense Increase incronse Increase inorea in wolght, in welght in weight, in wolght in woight, weight grams. of oil. grans. of 011. grems. of o11. grams.

\begin{tabular}{|c|c|c|c|}
\hline 0.0000 & 0.0 & 0.0000 & 0.0 \\
\hline 0.0000 & 0.0 & 0.0000 & 0.0 \\
\hline 0.0000 & 0.0 & 0.0000 & 0.0 \\
\hline 0.0000 & 0.0 & 0.0000 & 0.0 \\
\hline 0.0000 & 0.0 & 0.0000 & 0.0 \\
\hline 0.0000 & 0.0 & 0.0000 & 0.0 \\
\hline 0.0002 & 0.1 & 0.0008 & 0.1 \\
\hline $0.060 ?$ & 0.1 & 0.0005 & 0.2 \\
\hline 0.0030 & 1.5 & 0.0007 & 0.3 \\
\hline 0.0066 & 3.2 & 0.0009 & 0.4 \\
\hline 0.0105 & 5.1 & 0.0011 & 0.5 \\
\hline 0.0112 & 6.9 & $0.00 \times 1$ & 1.9 \\
\hline 0.0183 & 8.9 & 0.0034 & 2.4 \\
\hline 0.0223 & 10.6 & 0.0203 & 9.4 \\
\hline 0.018 & 11.6 & 0.0250 & 11.6 \\
\hline 0.0263 & 13.8 & 0.1060 & 12.5 \\
\hline 0.0976 & 13.4 & - &  \\
\hline 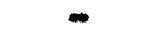 & - & 0.0278 & 12.9 \\
\hline- & 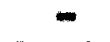 & 0.0878 & 12.9 \\
\hline 0.0261 & 12.7 & 0.0275 & .7 \\
\hline
\end{tabular}


Table 11

Dryine dete for linseed oil containine 2. Fams lend and 20 prams bone black per 100 prems oil. (Pereent oil, 78.0)



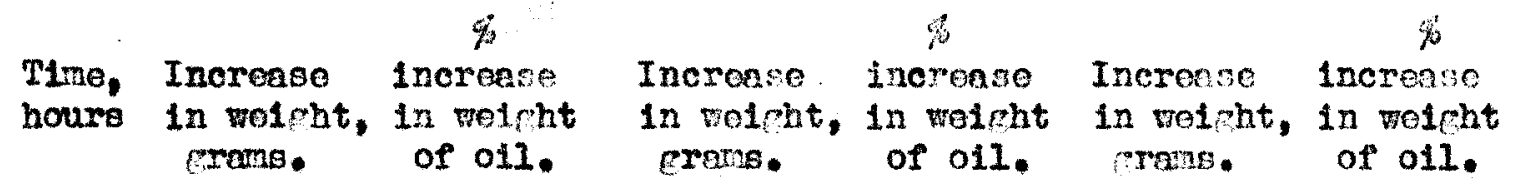

\begin{tabular}{|c|c|c|c|c|c|c|}
\hline 1 & 0.0000 & 0.0 & 0.0000 & 0.0 & 0.0000 & 0.0 \\
\hline 2 & 0.0000 & 0.0 & 0.0000 & 0.0 & 0.0002 & 0.1 \\
\hline 3 & 0,0000 & 0.0 & 0.0000 & 0.0 & 0.0002 & 0.1 \\
\hline 4 & 0.0000 & 0.0 & 0.0000 & 0.0 & 0.0002 & 0.1 \\
\hline 5 & 0.0003 & 0.2 & 0,0000 & 0.0 & 0.0002 & 0.1 \\
\hline 6 & 0.0003 & 0.2 & 0.0000 & 0.0 & 0.0008 & 0.1 \\
\hline 7 & 0.0003 & 0.2 & 0.0003 & 0.1 & $0.000^{\circ}$ & 0.1 \\
\hline 8 & 0.0010 & 0.6 & 0.0003 & 0.1 & 0.0002 & 0.1 \\
\hline 9 & 0.0085 & 1.6 & 0,0003 & 0.1 & 0.0002 & 0.1 \\
\hline 10 & 0.0031 & 2.1 & 0.0008 & 0.1 & 0.0002 & 0.1 \\
\hline 11.5 & 0.0059 & 3.7 & 0.0004 & 0.2 & 0.0002 & 0.1 \\
\hline 13 & 0,001 & 5.1 & 0.0006 & 0.3 & 0.0007 & 0.4 \\
\hline 15 & 0.0213 & 7.1 & 0.003 & 1.6 & 0.0032 & 1.7 \\
\hline 17 & 0.0136 & 0.5 & 0.0073 & 3.5 & 0.0060 & 3.2 \\
\hline 30 & 0.0260 & 10.0 & 0.0144 & 7.0 & 0.0107 & 5.7 \\
\hline 24 & 0.0282 & 11.4 & 0.0196 & 9.5 & 0.0149 & 8.0 \\
\hline 28 & 0.0196 & 12.3 & 0.0232 & $11 \cdot 2$ & - & 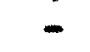 \\
\hline 32 & - & - & - & - & 0.0192 & 10.2 \\
\hline 39 & - & - & - & - & 0.0217 & 11.7 \\
\hline 48 & - & - & 0.0244 & 11.8 & 0.0221 & 11.9 \\
\hline 50 & 0.0209 & 13.1 & - & - & - & 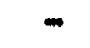 \\
\hline
\end{tabular}




$$
\text { FIG. II DRYING RATE OF LINSEED OIL }
$$

CONTAINING 20 GRAMS OF LEAO PER 100 GRAMS OIL
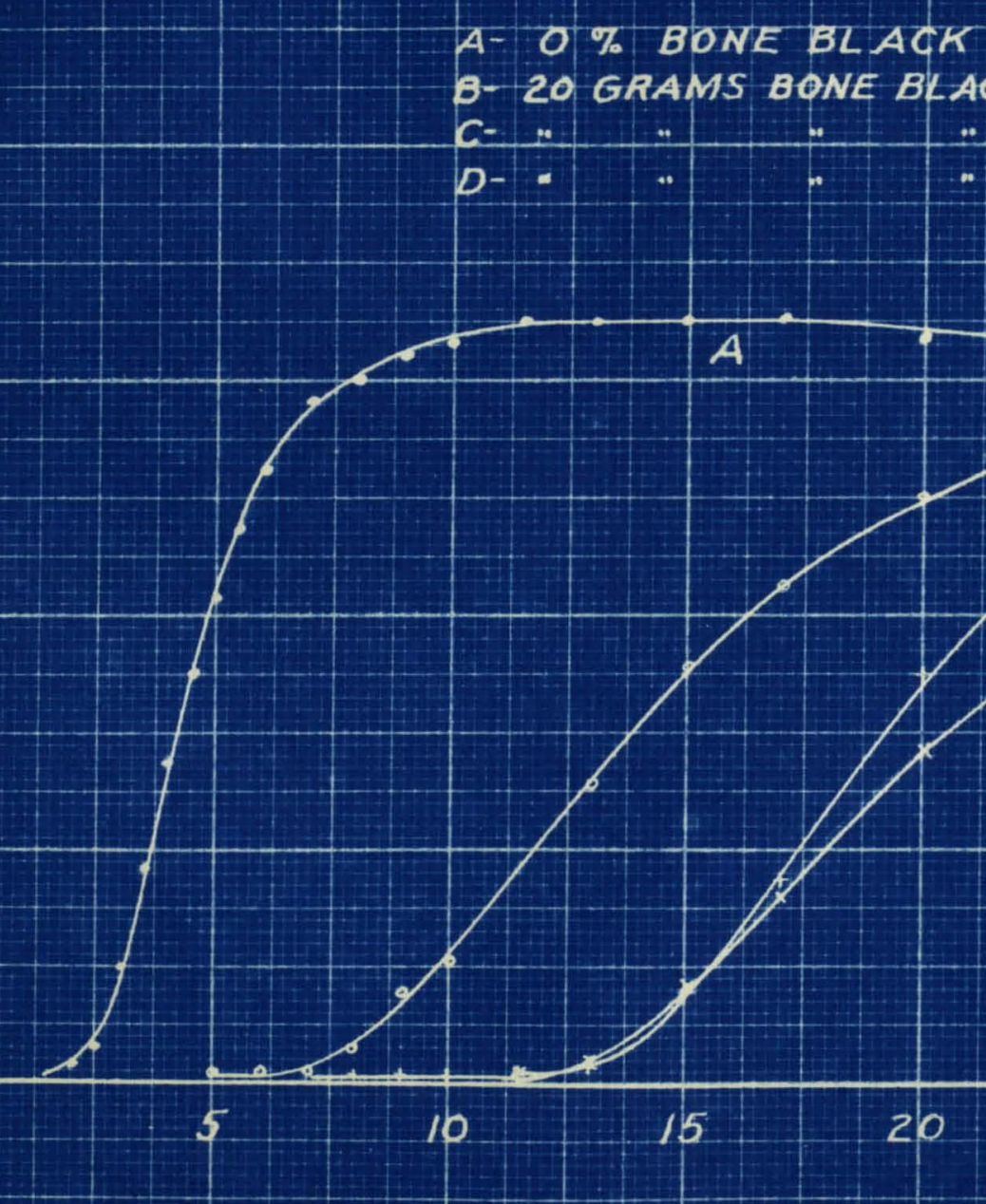

20
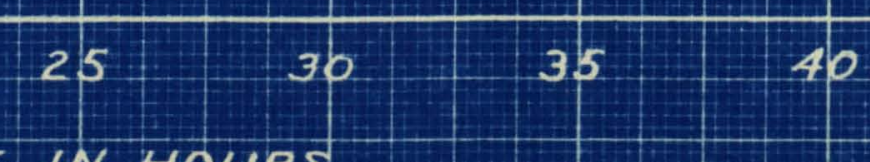
TIME IN HOURS 
The drying curvos for IInseed oll contalning lead drier and bone black, Figures 8, 9, 10, and 11, show, unlike the curves for aarbon black mixtures, an induction period for the froshly made bone black anmles about two to ten times as long as the Induction pertod for unplgmented oll. Aløo unlike the carbon bleck curres, the bone black curves have a alope different from the slope of unplemented oll curves, showing that bone bleck affects the rate of drying during the constant rate period. The offect of aging lo to increase greatly the Induction period and hence the time of final drying. Increase of dryIng time greater for mixtures of higher bone black concentration; this corresponded to the behavior of carbon black sarxples. The 10as of arying power with increase in age was much greater for bone bleck mixtures was mach greater than for corresponding carbon black mixtureo. 
Table 12

Dryine ante for 1 inseed oll contelnint 1 gram lead and 7 grom lam black per 100 (rams oll. (Percant o1l, 90.8)

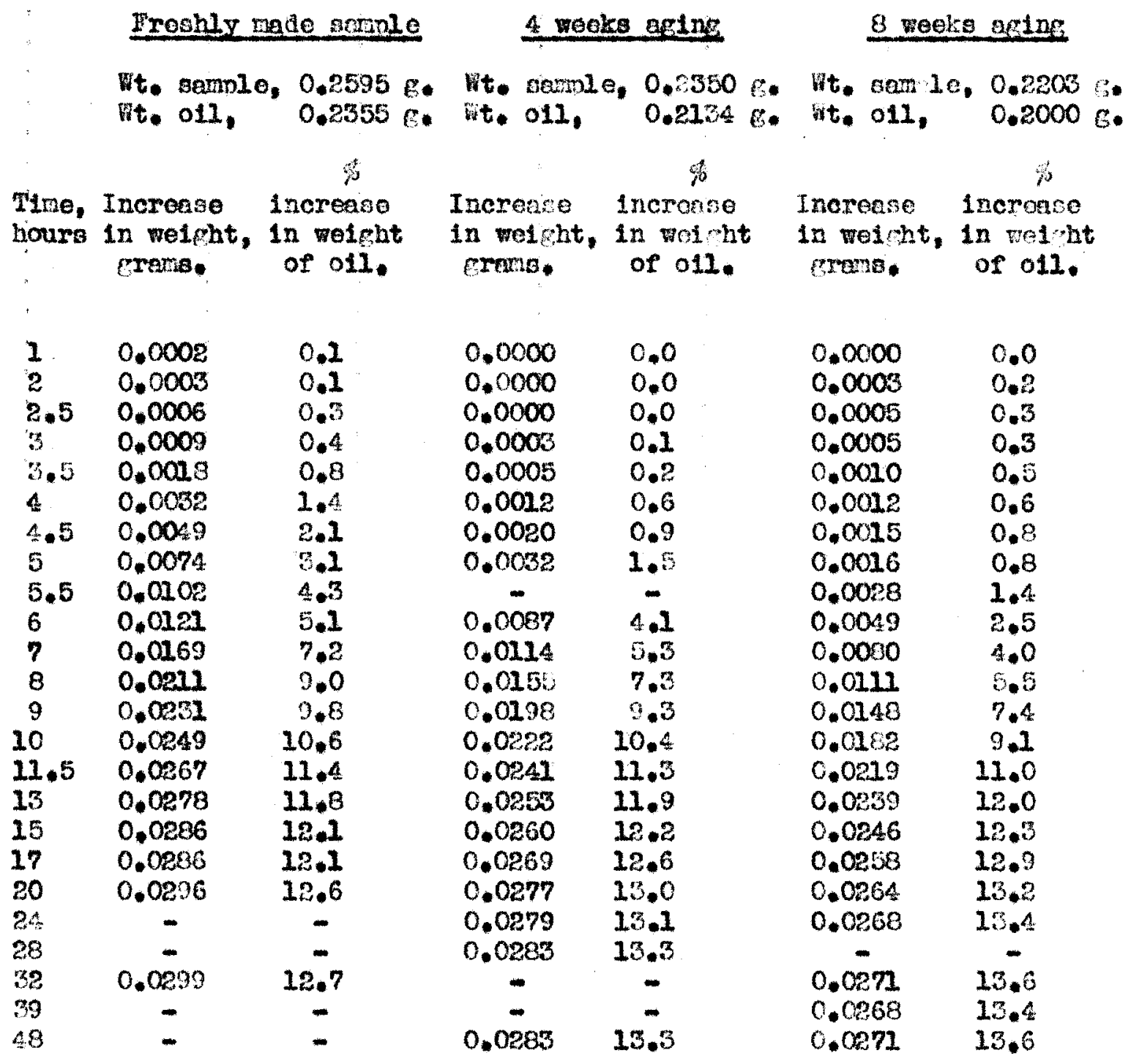


FIG 12 DRYING RATE OF LINSEED OIL CONTAINING IO GRAM OF LEAD PER IOO GRAMSOLL

A- 0\% LAMP BL ACK

B- 7 GRAMS LAMP BLACK PER 100 GRAMS OIL; FRESHLY MADE

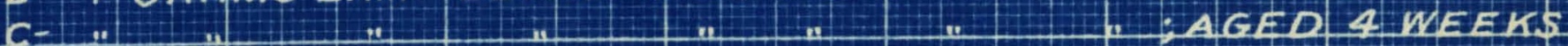

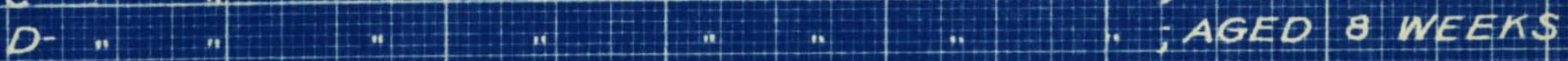

$\frac{0}{1}$

o 12 人

10

(

4

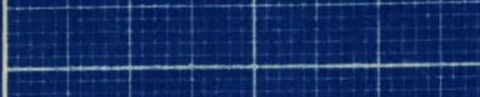

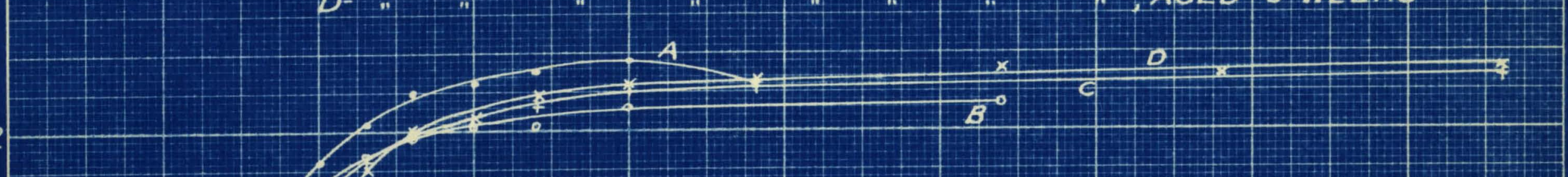

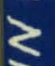


Table 13

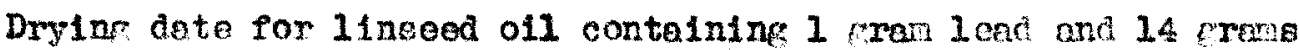
Iarm black per 100 prams 011. (Percont 011, 84.5)

Freshly made sanzle

Wt. semole, 0.3015 ?. Fit. 011,
4 meairs ofing

Wt. sannle, $0.2298 \mathrm{~g}$. Ft. sannle, $0.2201 \mathrm{~g}$. itt. o11, 0.1940 it. o11. 0.1860

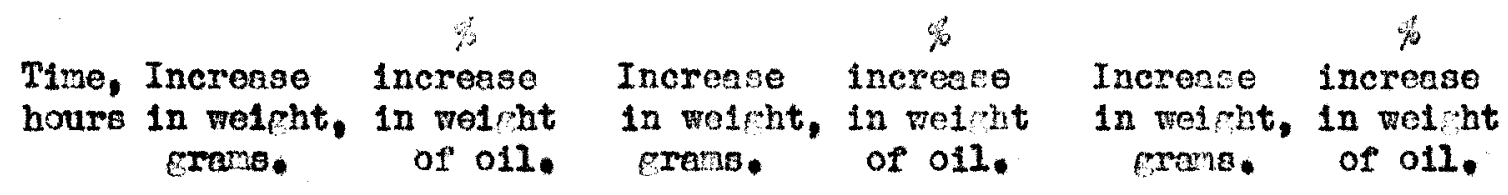

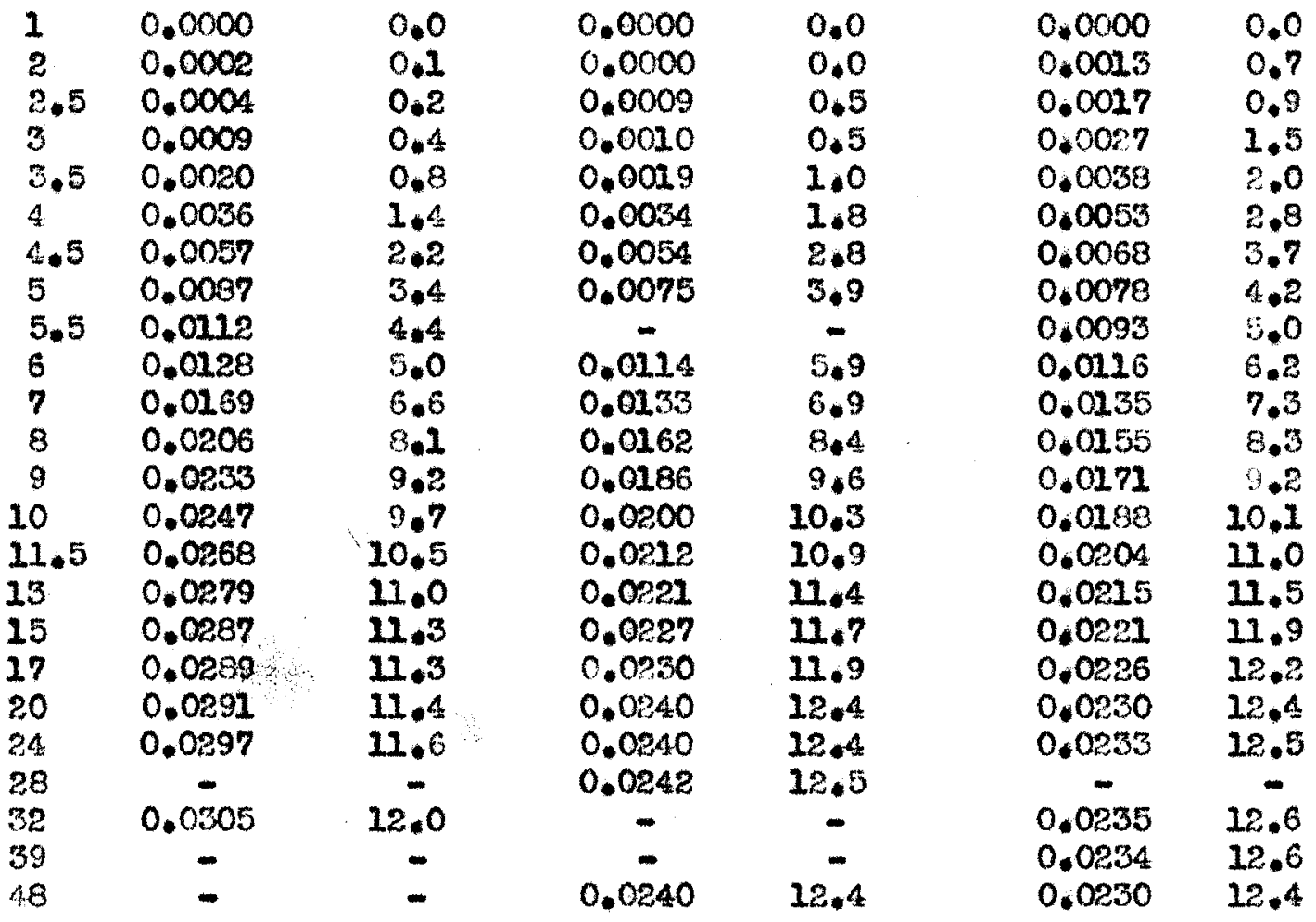


FIG 13 DRYING RATE OF LINSEED OIL

CONTAINING 10 gRIAM OF LEAD PER 100 gRAMS OLL

A-0\% LAMP BLACK

B-14 GRAMS LAMP ELAGK PER 100 GRAMS OIL; FHESHLY MADE

C."

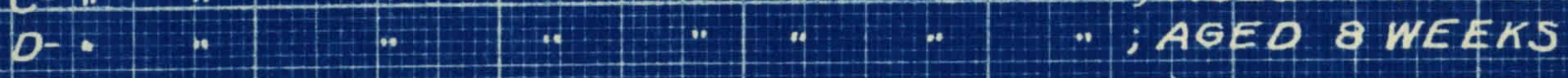

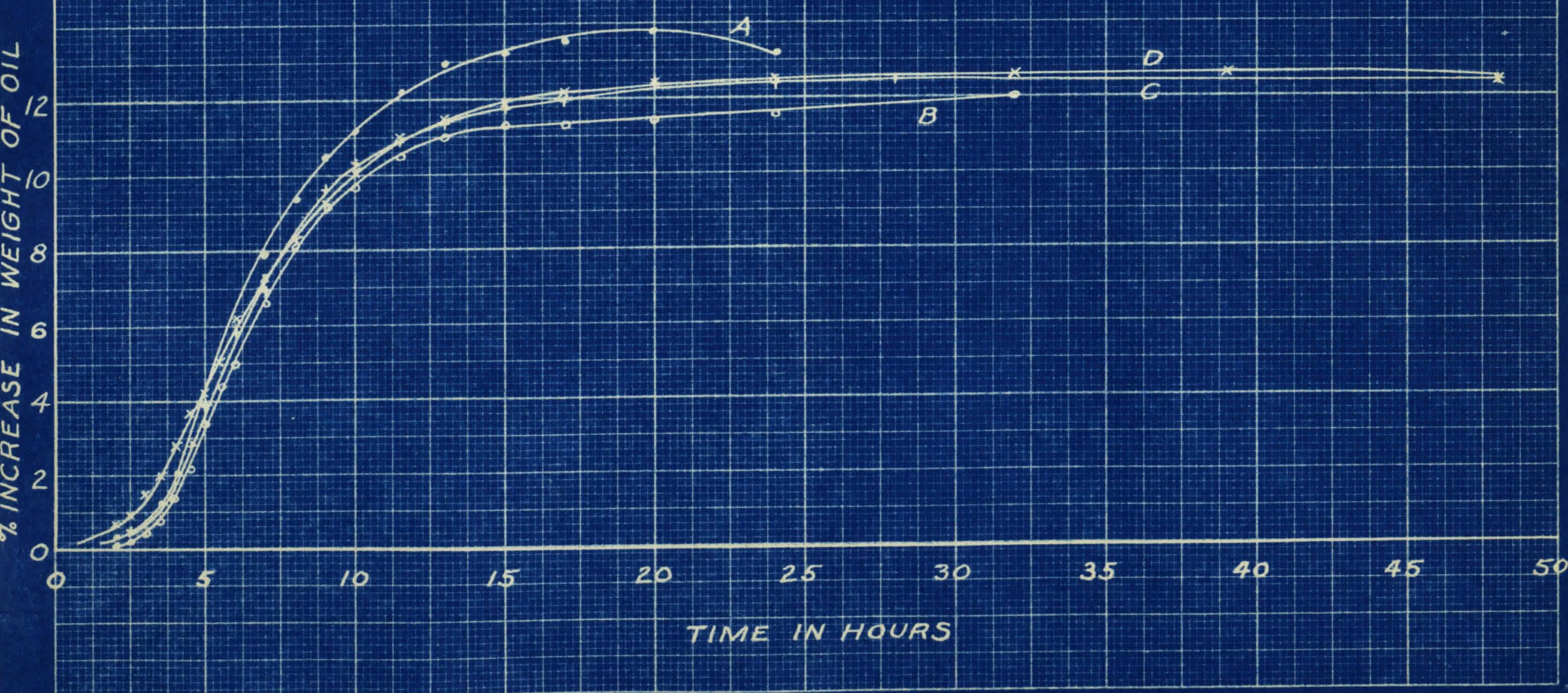


Teble 14

Drying date for 11 need o11 contalning 2 grams 1 ad and 7 grane lamp black per 100 grame o11. (Poxcont 011, 36.8)






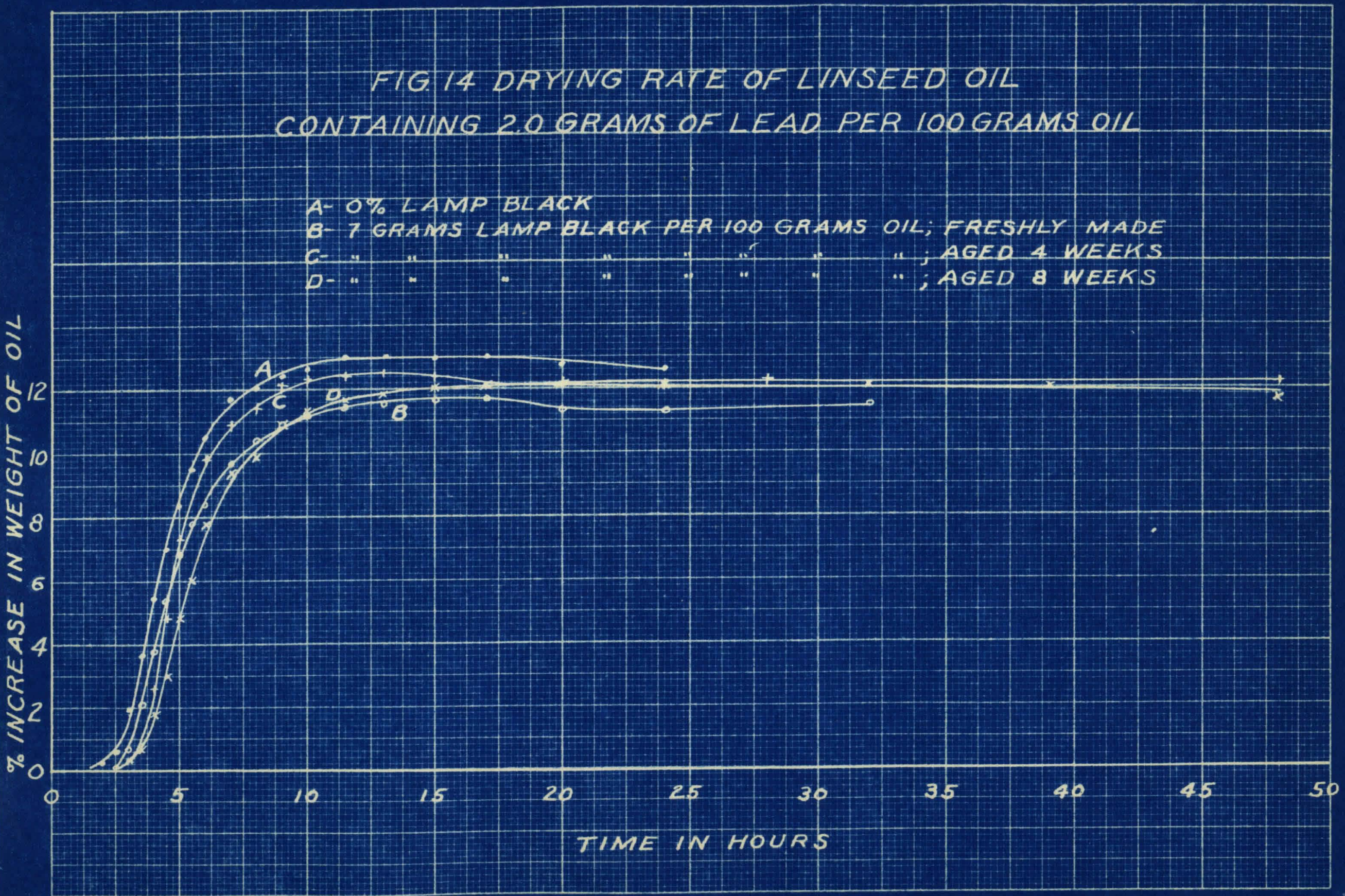


Table 15

Drying data for linseed o1l containinf 2 prems load and 14 prena 2amp black per 100 grame 011. (Percent 011, 81.7)

Freshly made anale

4 weoks agins

Wt. sample, 0,3288 g. Ft. ample, $0,2680 \mathrm{~g}$. Ft. o11. $0.2682 \mathrm{~g}$ Wt. eamplo,
Vt. o11. $0.2186 \mathrm{E}$ 7t. sample, 0,2084 G. Wit. 011, 0.1702 E.

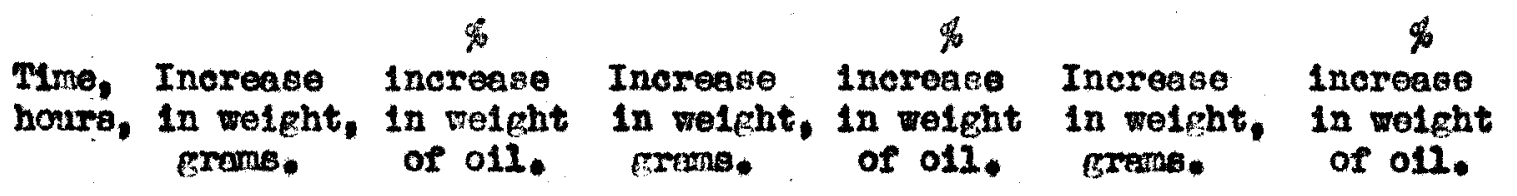

\begin{tabular}{|c|c|c|c|c|c|}
\hline $\begin{array}{l}1 \\
2 \\
2.5 \\
3 \\
3.5 \\
4 \\
4.5 \\
5 \\
5.5 \\
6 \\
7 \\
8 \\
9 \\
10 \\
11.5 \\
13 \\
13 \\
17 \\
20 \\
24 \\
28\end{array}$ & $\begin{array}{c}0.0000 \\
0.0000 \\
0.0004 \\
0.0016 \\
0.0046 \\
0.0209 \\
0.0129 \\
0.0151 \\
0.0280 \\
0.0895 \\
0.0232 \\
0.0258 \\
0.0270 \\
0.0280 \\
0.0289 \\
0.0294 \\
0.0294 \\
0.0292 \\
0.0294 \\
0.0298 \\
0.0301 \\
-\end{array}$ & $\begin{array}{c}0.0 \\
0.0 \\
0.2 \\
0.6 \\
1.7 \\
4.1 \\
4.4 \\
5.6 \\
6.7 \\
7.3 \\
8.7 \\
9.5 \\
10.1 \\
10.4 \\
10.7 \\
11.0 \\
11.0 \\
10.9 \\
11.0 \\
11.2 \\
11.2 \\
-0 \\
-\end{array}$ & $\begin{array}{c}0.0000 \\
0.0000 \\
0.0000 \\
0.0002 \\
0.0004 \\
0.0017 \\
0.0058 \\
0.0097 \\
0.0160 \\
0.0285 \\
0.0210 \\
0.0231 \\
0.0243 \\
0.0247 \\
0.0253 \\
0.0258 \\
0.0255 \\
0.0259 \\
0.0259 \\
0.0263 \\
- \\
0.0256\end{array}$ & $\begin{array}{r}0.0 \\
0.0 \\
0.0 \\
0.1 \\
0.2 \\
0.8 \\
2.7 \\
4.4 \\
7.3 \\
8.5 \\
9.6 \\
10.6 \\
11.1 \\
11.3 \\
11.6 \\
11.6 \\
11.7 \\
11.8 \\
11.8 \\
12.0 \\
. \\
11.7\end{array}$ & $\begin{array}{r}0.0000 \\
0.0003 \\
0.0003 \\
0.0003 \\
0.0007 \\
0.0021 \\
0.0045 \\
0.0058 \\
0.0080 \\
0.0215 \\
0.0148 \\
0.0267 \\
0.0184 \\
0.0196 \\
0.0202 \\
0.0203 \\
0.0207 \\
0.0209 \\
0.0211 \\
0.0209 \\
0.0207 \\
0.0210 \\
0.0201\end{array}$ \\
\hline
\end{tabular}




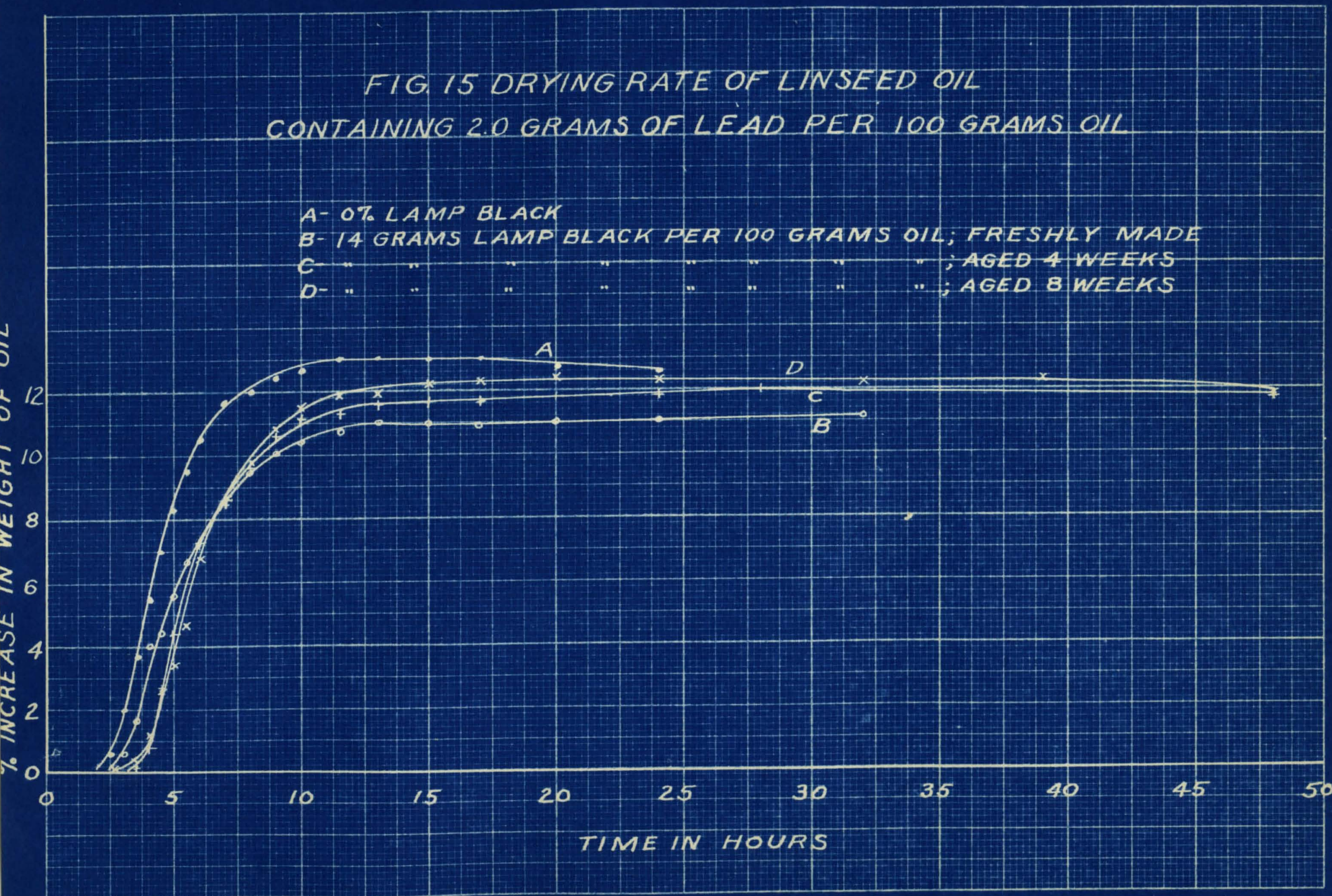


The arying curves for linseed oll containing lead drier and lamp black, Flgures 12, 13, 14, and 15, show very amall difference in Induction pertod between freshly made lamo black samples and unpigmented 011, and practioally no difference in induction period betwoen the Ireahly made samples and the same semples when aged. The dxylng of the lamp black aamples wae very similar to the arying of unpignented 011. The larm black cemplea, unlike the carbon black camples and the bone black samples, showed no appreclable loss in dryine power at four woaks and elght weaks time after preparation. 
Table 16

Dryine date for $11 n s e 0 d$ oil containing 1 gram 1 cad and 14 grams eraphite per 100 grems 011. (Peroent o11, 84,7)

Ereahly mace oample. 4 veeks aring 8 rooks actins

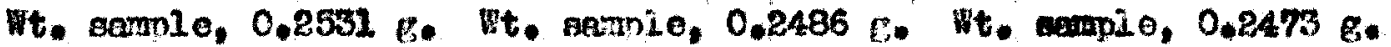
Ft. 011, 0.2140 is. Wt. 011, 0.2105 g. Wt. 011, 0.2094 g.

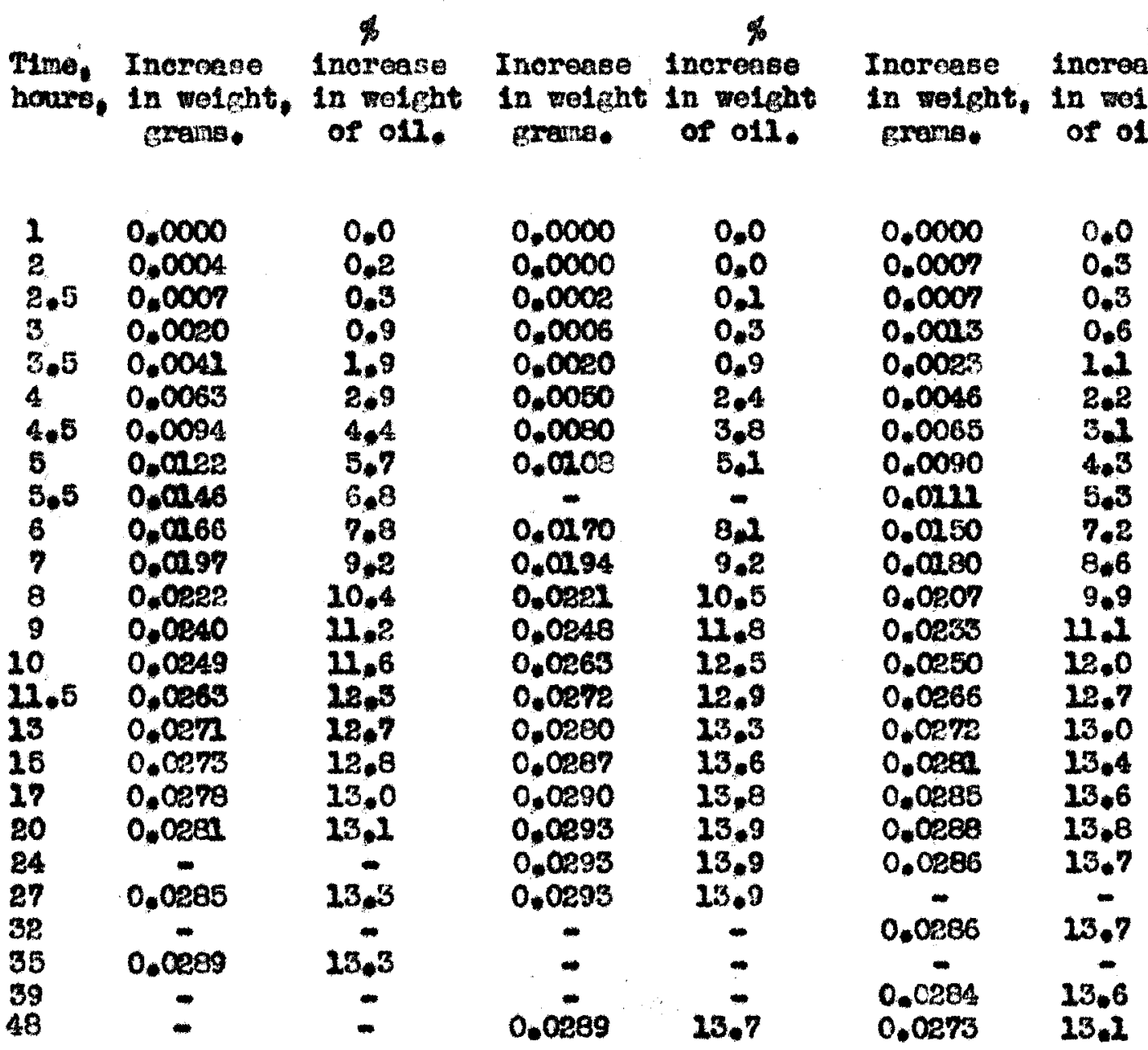







Table 17

Drylne data for linseed oll contalning a crams lead and 14 grams Eraphite per 100 crang 011. (Porcont o11, 81.9)

\section{Freahly made samie 4 reoks aglns 8 reeks aging}

Ft. sample, $0.2766 \mathrm{~g} . \mathrm{Ft}$. samplo, $0.2537 \mathrm{~g}$. Wt. sample, $0.2937 \mathrm{~g}$. Ft. 011, 0.2264 E. Wt. 011, $0.2074 \mathrm{~g}$. Wt. 011, $0.2400 \mathrm{~g}$.

\begin{tabular}{|c|c|c|c|c|c|c|}
\hline Time, & $\begin{array}{l}\text { Increase } \\
\text { in weight, } \\
\text { erams. }\end{array}$ & $\begin{array}{l}\% \\
\text { Increase } \\
\text { in weight } \\
\text { of otl. }\end{array}$ & $\begin{array}{l}\text { Increase } \\
\text { in we1rht, } \\
\text { grans. }\end{array}$ & $\begin{array}{l}\text { increase } \\
\text { in meight } \\
\text { of oll. }\end{array}$ & $\begin{array}{l}\text { Incrense } \\
\text { in retreht, } \\
\text { grame. }\end{array}$ & $\begin{array}{l}\text { ine } \\
\text { in } \\
\text { of }\end{array}$ \\
\hline 1 & 0.0000 & 0.0 & 0.0000 & 0.0 & 0.0000 & 0. \\
\hline 2 & 0.0000 & 0.0 & 0.0004 & 0.2 & 0.0000 & 0. \\
\hline 2.5 & 0.0022 & 0.5 & 0.0025 & 1.1 & 0.0003 & 0. \\
\hline 3 & 0.0047 & 2.1 & 0.0040 & 1.9 & 0.0013 & 0.5 \\
\hline .5 & 0.0096 & $4 . ?$ & 0.0071 & 3.4 & 0.0030 & 1.8 \\
\hline 4 & 0.0131 & 5.3 & 0.0119 & 5.7 & 0.0077 & 3.2 \\
\hline 4.5 & 0.0165 & 7.3 & 0.01 .9 & 7.8 & 0.0209 & 4.5 \\
\hline 5 & 0.0183 & 8.3 & 0.0173 & 8.3 & 0.0145 & 6.0 \\
\hline 5.5 & 0.0207 & 9.1 & - & - & 0.0169 & 7.0 \\
\hline 6 & 0.0220 & 9.7 & 0.0200 & 10.0 & 0.0201 & 8.4 \\
\hline 7 & 0.0244 & 10.8 & 0.0219 & 10.6 & 0.0225 & 3.4 \\
\hline 8 & 0.02 .54 & 11.2 & 0.0231 & 11.1 & 0.0243 & 10.1 \\
\hline 9 & 0.0262 & 11.5 & 0.0241 & 11.6 & 0.0056 & 10.7 \\
\hline 10 & 0.0267 & 11.8 & 0.0244 & 11.8 & 0.0264 & 11.0 \\
\hline 11.5 & 0.0272 & 12.0 & 0.0246 & 11.9 & 0.0271 & 11.3 \\
\hline 13 & 0.0274 & 28.1 & 0.0849 & 12.0 & 0.0877 & 11.5 \\
\hline 15 & 0.0274 & 12.1 & 0.0249 & 12.0 & 0.0279 & 11.6 \\
\hline 17 & 0.0274 & 12.1 & 0.0847 & 11.9 & 0.0381 & 11.7 \\
\hline 20 & 0,0275 & 12.1 & 0.0247 & 11.9 & 0.0281 & 11.7 \\
\hline 24 & - & - & $0.02,47$ & 11.9 & 0.0281 & 11. \\
\hline 87 & 0.0 .76 & 12.2 & 0.0247 & 11.9 & - &  \\
\hline 32 & - & - & - & - & 0.0278 & 11.6 \\
\hline 35 & 0.0274 & 12.1 & - & - & - & - \\
\hline 39 & - & - & - & - & 0.074 & 11. \\
\hline 48 & - & - & 0.0245 & 11.8 & 0.0208 & 1.6 \\
\hline
\end{tabular}




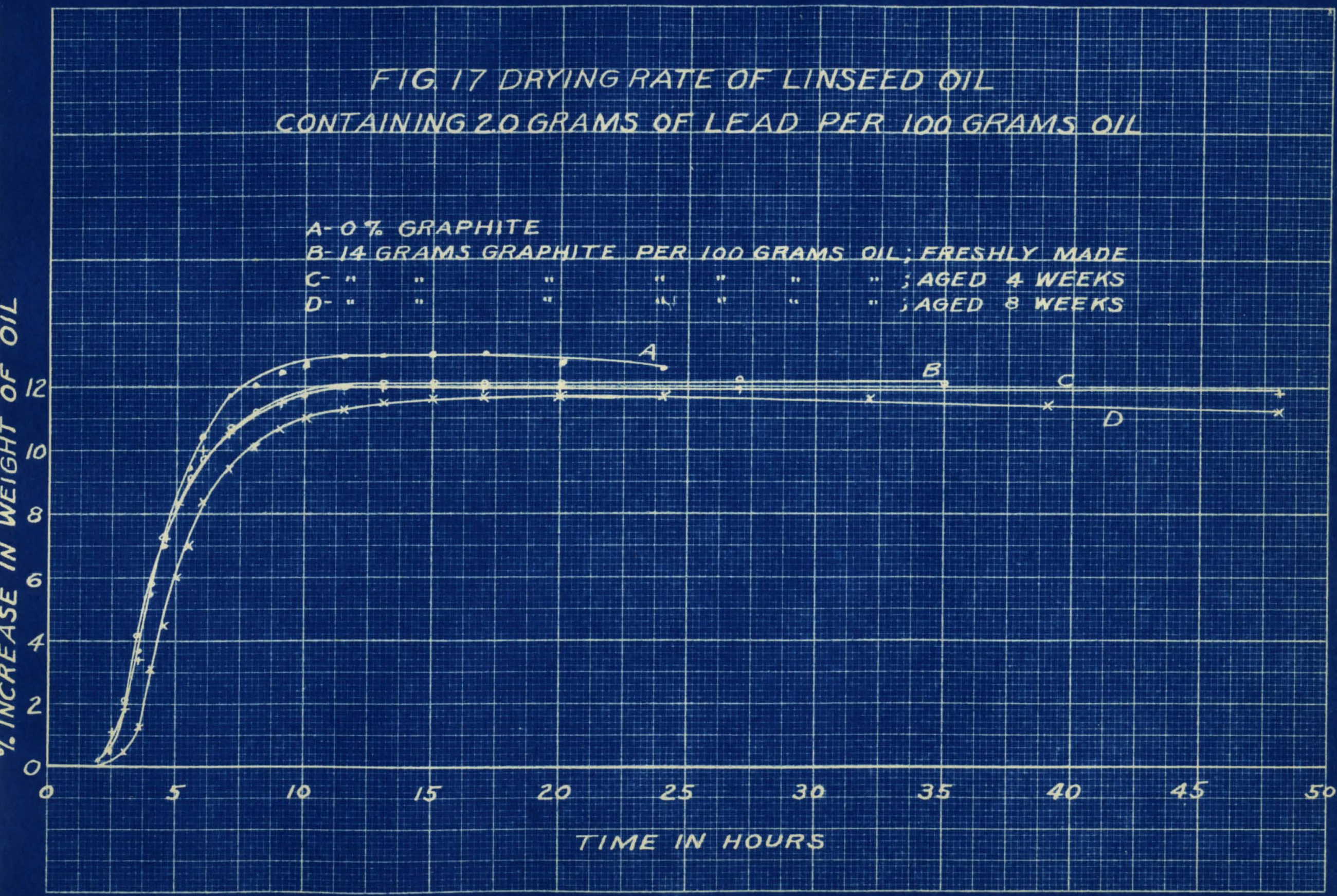


Table 18

Dryine date for 1 inseed oil contolning 1 fram lead and 28 grans aranht te per 100 grems o11. (Percent 011, 75.7)



Wt. aamle, 0.2051 g. Wt. sarmle, $0.2583 \mathrm{g.W}$ Wt. sample, $0.3389 \mathrm{~g}$. Ft. 011, 0.1551 E. Wt. 011, $0.1956 \mathrm{E}$. Ft, o11, 0.2565 g.

\begin{tabular}{|c|c|c|c|c|c|c|}
\hline $\begin{array}{l}\text { Time, } \\
\text { hours }\end{array}$ & $\begin{array}{l}\text { Inorease } \\
\text { In welght, } \\
\text { Erams. }\end{array}$ & $\begin{array}{l}\text { increase } \\
\text { in melfht } \\
\text { of oil. }\end{array}$ & $\begin{array}{l}\text { Increase } \\
\text { in roleht, } \\
\text { frems. }\end{array}$ & $\begin{array}{l}\text { incroabe } \\
\text { in reipht } \\
\text { of oll. }\end{array}$ & $\begin{array}{l}\text { Incroase } \\
\text { In woicht, } \\
\text { grang. }\end{array}$ & in \\
\hline 1 & 0.0000 & 0.0 & 0.0000 & 0.0 & 0.0000 & $U$ \\
\hline 2 & 0.0013 & 0.8 & 0.0010 & 0.5 & 0.0000 & \\
\hline 2.5 & 0.0026 & 1.7 & 0.0039 & 2.0 & 0.0014 & 0 \\
\hline 3 & 0.0044 & 2.8 & 0.0055 & 2.8 & 0.0042 & \\
\hline 3.5 & 0.0059 & 5.8 & 0.0080 & 4.1 & 0.0062 & 2.4 \\
\hline 4 & 0.0079 & 5.1 & 0.0214 & 5.8 & 0.0111 & \\
\hline 4.5 & 0.0095 & 6.1 & 0.0145 & 7.4 & 0.0136 & \\
\hline 5 & 0.0180 & 7.7 & 0.0169 & 8.6 & 0.0163 & \\
\hline 5.5 & 0.0133 & 8.6 & - & - & 0.0188 & \\
\hline 6 & 0.0149 & 9.6 & 0.0203 & 10.4 & 0.0217 & \\
\hline 7 & 0.0166 & 10.7 & 0.0210 & 10.7 & $0.02: 39$ & \\
\hline 8 & 0.0186 & 12.0 & 0.0224 & 21.5 & 0.0259 & 10 \\
\hline 9 & 0.0200 & 12.9 & 0.0234 & 12.0 & 0.0276 & \\
\hline 10 & 0.0205 & 13.5 & 0.0041 & 12.3 & 0.0290 & 11 \\
\hline 11.5 & 0.0209 & 13.6 & 0.0242 & 12.4 & 0.0097 & 11 \\
\hline 13 & 0.0209 & 13.5 & 0.0246 & 12.6 & 0.0301 & \\
\hline 15 & 0.0209 & 13.5 & 0.0248 & 12.7 & 0.0308 & 12.0 \\
\hline 17 & 0.0209 & 13.5 & 0.0250 & 12.8 & 0.0312 & 12.2 \\
\hline 20 & 0.0207 & 13.8 & 0.0255 & 15.0 & 0.0317 & 12. \\
\hline 24 & 0.0205 & 13.2 & 0.0255 & 13.0 & 0.0 .17 & \\
\hline 28 & 0.0201 & 13.0 & 0.0349 & 12.7 & - & \\
\hline 32 & - & - & - & - & $0.0 \% 17$ & 12 \\
\hline 39 & - & - & - & - & 0.000 & 12 \\
\hline 48 & - & - & 0.0848 & 15.7 & 0.0301 & 1.1 \\
\hline 50 & 0.0196 & 12.6 & - & - & - & \\
\hline
\end{tabular}




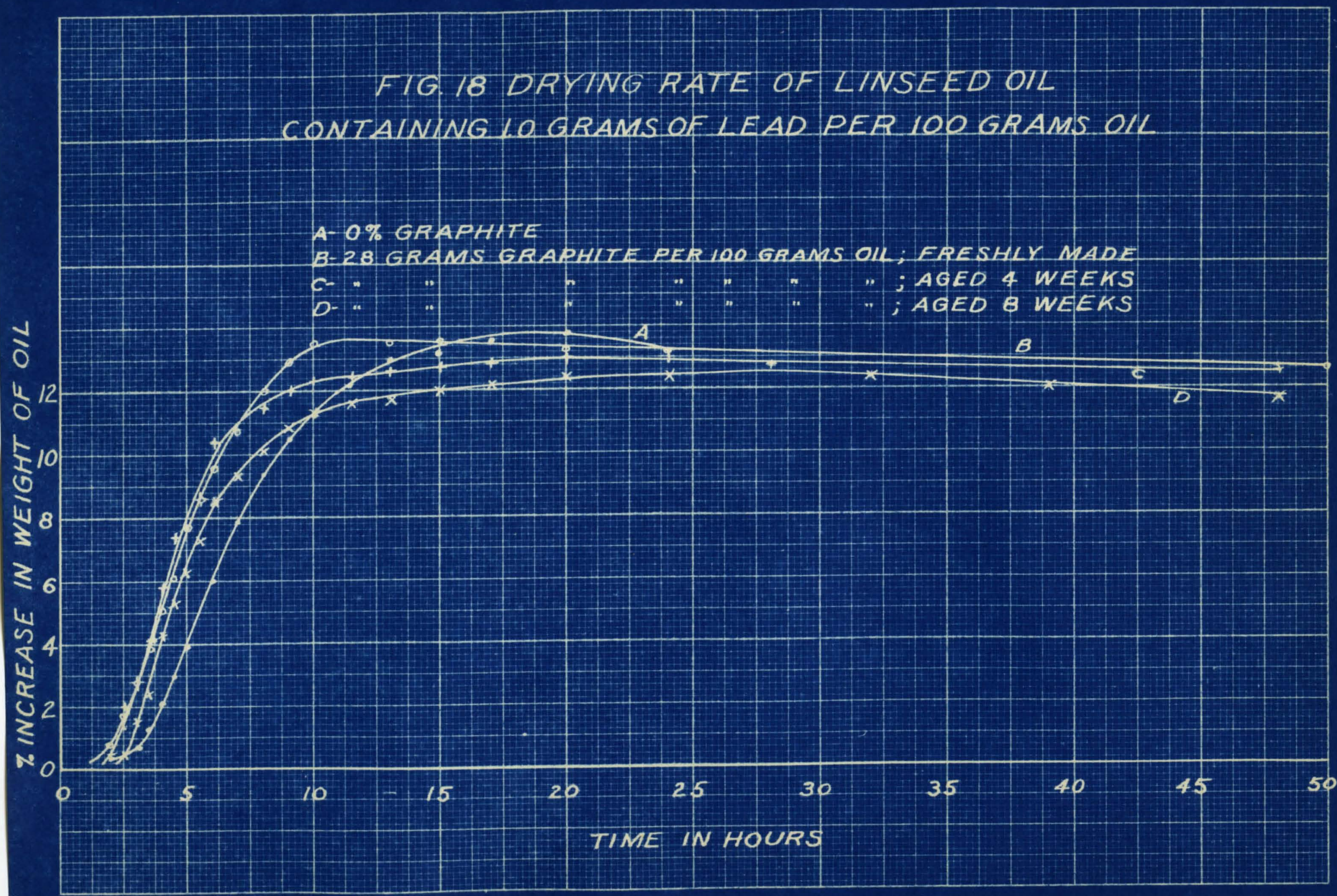


Table 19

Drying dote for linsece ofl containine? rrone lond and so rans cranhlte ner 100 erme oil. (Percent o11, 75.:3)

\section{Froshly made samio 4 gecks aging 8 reoks aglng}

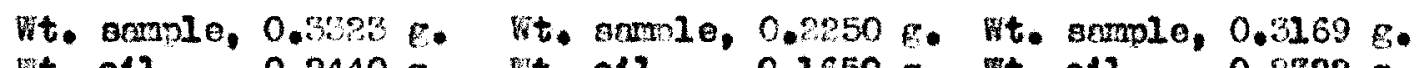
Wt. 011, 0.2440 E. Wt. 011, $0.1650 \mathrm{~g}$. wt. o11, $0.2322 \mathrm{E}$.

\begin{tabular}{|c|c|c|c|c|c|c|}
\hline $\begin{array}{l}\text { Time, } \\
\text { hours }\end{array}$ & $\begin{array}{l}\text { Incroase } \\
\text { in molpht, } \\
\text { erans. }\end{array}$ & $\begin{array}{l}\text { of } \\
\text { Increase } \\
\text { in weint } \\
\text { of oll. }\end{array}$ & $\begin{array}{l}\text { Increase } \\
\text { in wel rht, } \\
\text { Erris. }\end{array}$ & $\begin{array}{c}\text { s } \\
\text { Incroaso } \\
\text { in el tht } \\
\text { of oll. }\end{array}$ & $\begin{array}{l}\text { Increase } \\
\text { in veloht, } \\
\text { mans. }\end{array}$ & $\begin{array}{l}\text { कs } \\
\text { increase } \\
\text { in vel ht } \\
\text { of oll. }\end{array}$ \\
\hline 1 & 0.0000 & 0.0 & 0.0000 & 0.0 & 0.0000 & 0.0 \\
\hline 2 & 0.0009 & 0.4 & 0.0007 & 0.4 & 0.0600 & 0.0 \\
\hline 2.5 & 0.0023 & 0.9 & $0.00 \mathrm{~s}$ & 1.4 & 0.0017 & 0.7 \\
\hline 3 & 0.0057 & 2. & 0.0042 & 2.5 & 0.0028 & 1.6 \\
\hline 3.5 & 0.0034 & 8.4 & 0.0065 & 3.9 & 0.0060 & 2.6 \\
\hline 4 & 0.0123 & 3.0 & 0.0100 & 6.1 & 0.0118 & 5.1 \\
\hline 2.6 & 0.0144 & 5.9 & 0.01 .1 & 7.3 & 0.0142 & 6.1 \\
\hline 5 & 0.0183 & 7.5 & 0.0136 & B.2 & 0.0168 & 7.2 \\
\hline 5.5 & 0.0202 & 8.3 & - & - & 0.0283 & 7.9 \\
\hline 6 & 0.0217 & 8.9 & 0.0163 & 9.9 & 0.0203 & 8.7 \\
\hline 7 & 0.0241 & 9.9 & .0168 & 10.2 & 0.0221 & 9.5 \\
\hline 8 & 0.0259 & 10.6 & 0.0275 & 10.6 & 0.0231 & 9.8 \\
\hline 9 & 0.0270 & 11.1 & 0.0177 & 10.7 & $0,00,1$ & 10.4 \\
\hline 10 & 0.0277 & 11.4 & 0.0177 & 10.7 & 0.0250 & 10.8 \\
\hline 11.5 & $0.02,81$ & 11.5 & 0.0178 & 10.8 & 0.0253 & 10.9 \\
\hline 13 & 0.0283 & 11.6 & 0.0178 & 10.8 & 0.0258 & 11.1 \\
\hline 15 & 0.0283 & 11.6 & 0.0178 & 10.8 & 0.0259 & 11.2 \\
\hline 17 & 0.0 .83 & 11.6 & 0.0178 & 10.8 & 0.0262 & 11.5 \\
\hline 20 & $0 . \cap 283$ & 11.6 & 0.0178 & 10.8 & 0.0265 & 11.5 \\
\hline 24 & 0.0083 & 11.6 & 0.0173 & 10.5 & 0.0263 & 11.3 \\
\hline 88 & 0.0385 & 11.6 & 0.02 .71 & 10.4 & - & - \\
\hline 32 & - & - & - & - & 0.0264 & 11.4 \\
\hline 39 & - & - & - & - & 0.0260 & 11.2 \\
\hline 48 & - & - & 0,0171 & 10.4 & $0.024 x$ & 10.9 \\
\hline 50 & 0.0201 & 11.5 & - & - & - & - \\
\hline
\end{tabular}




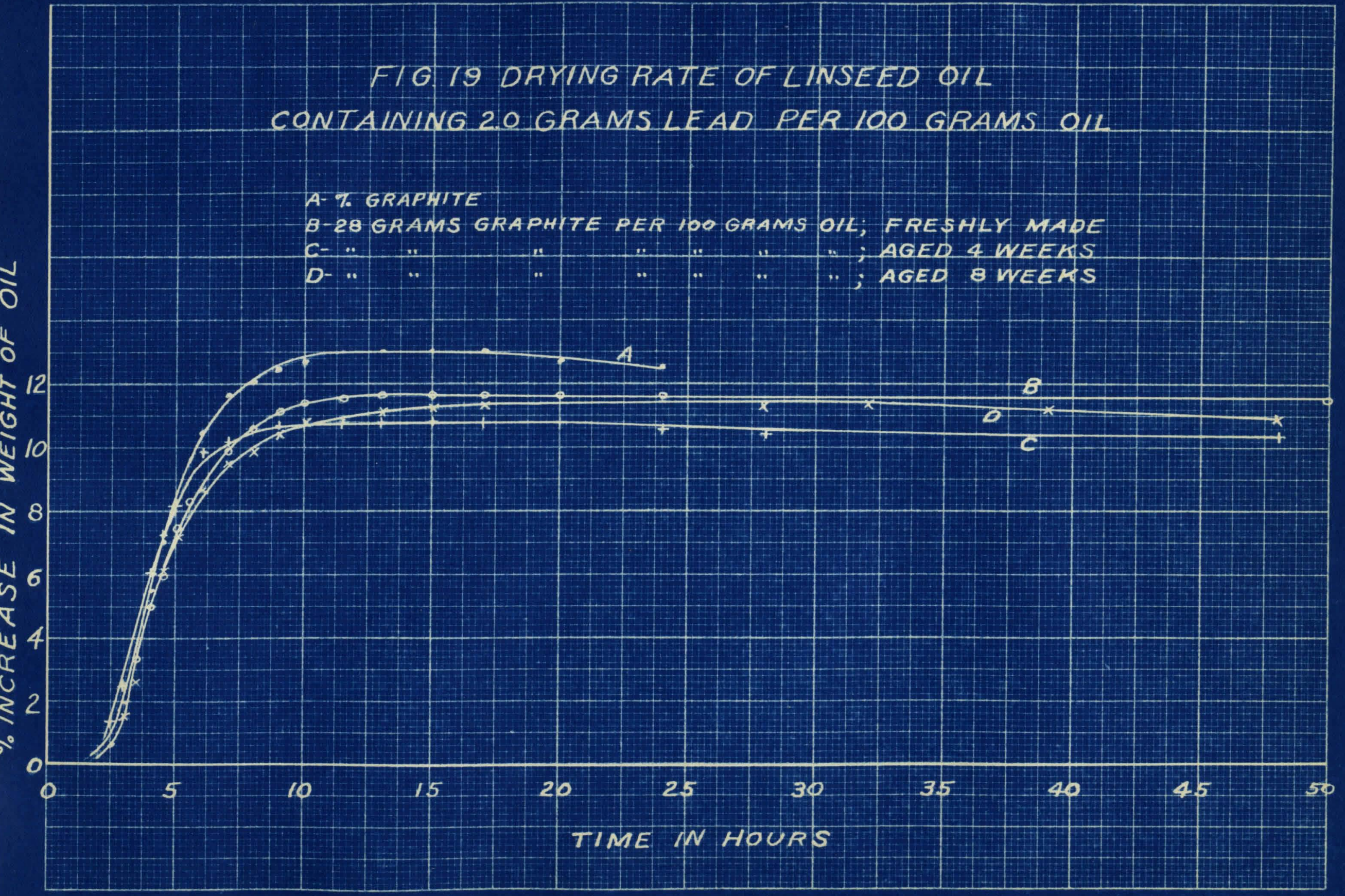


The arying curves for linseed oll containing lead drier and graphite, Fleures $16,17,18$, and 19, showed approxinately equal induction perlods, as was the case with the lamp black samles. The Grapht te samples vere also $11 k$ the lamp black samples in that the curves were simllar throughout the drging perlod, and that there was no great $108 s$ of arying power with incroase in age, up to elght weoks. 
Table 20

Dryins data for lincoed oil containine 0.95 gran cobalt and 3.5 Grams carbon black por 100. erans oll. (Porcent 011, 96.4)

Ereshly made sample

W. aanple, 0.2918 $\mathrm{g}$. it. oll, 0.2718 E.
A veokg aring

留t. sample, 0,2630 Wt. o11. $0.2585 \mathrm{~g}$.
8 veoks arine

Wt. sample, $0.2175 \mathrm{E}$ it. 011. $0.2085 \mathrm{~g}$.

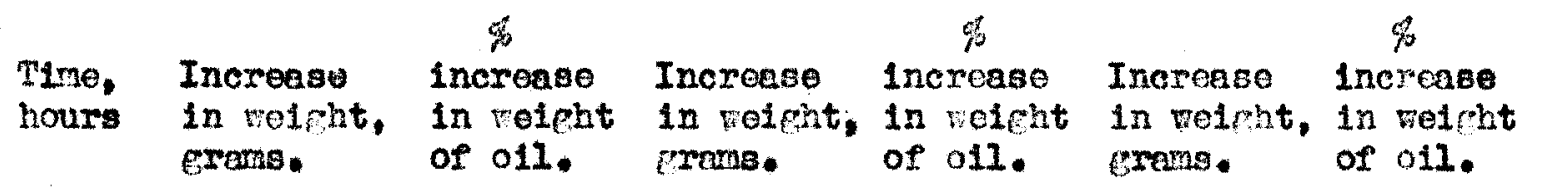

\begin{tabular}{|c|c|c|c|c|c|c|}
\hline 1 & 0.0000 & 0.0 & 0.0000 & 0.0 & 0.0000 & 0.0 \\
\hline 2 & 0.0000 & 0.0 & 0.0000 & 0.0 & 0.0007 & 0.5 \\
\hline 2.5 & 0,0000 & 0.0 & 0.0000 & 0.0 & 0.0007 & 0.3 \\
\hline 3 & 0.0003 & 0.1 & 0,0000 & 0.0 & 0.0007 & 0.3 \\
\hline 3.5 & 0,0015 & 0.6 & 0.0007 & 0.3 & 0.0007 & 0.3 \\
\hline 4 & 0.0026 & 1.0 & 0.0020 & 0.9 & 0.0009 & 0.4 \\
\hline 4.5 & 0.0049 & 1.8 & 0.0045 & 1.8 & 0.0009 & 0.4 \\
\hline 5. & 0.0074 & 2.7 & 0.0075 & 80 & 0.0002 & 0.4 \\
\hline 5.5 & 0.0104 & 3.8 & - & - & 0.0009 & 0.4 \\
\hline 6 & 0.0154 & 4.9 & 0.0137 & 5.4 & 0.0000 & 0.4 \\
\hline$\eta$ & 0.0296 & 7.2 & 0.0167 & 6.6 & 0,0009 & 0.4 \\
\hline 8 & 0.0237 & 8.7 & 0.02 .11 & 8.3 & 0.0009 & 0.4 \\
\hline 9 & 0.0270 & 9.9 & 0.0251 & 9.9 & 0.0009 & 0.4 \\
\hline 10 & 0.0996 & 10.9 & 0.0266 & 10.5 & 0.0009 & 0,4 \\
\hline 11.5 & 0.0306 & 11.3 & 0.0979 & 11.0 & 0.0012 & 0.6 \\
\hline 13 & 0.0312 & 11.5 & 0.0283 & 11.4 & 0.0028 & 1.3 \\
\hline 15 & 0.0320 & $11 \cdot 8$ & 0.0288 & 11.4 & 0.0068 & 2.3 \\
\hline 17 & 0.0321 & 11.8 & 0.0292 & 11.5 & 0.0118 & 5.7 \\
\hline 20 & 0.0319 & 11.7 & 0.0294 & 11.6 & 0.0208 & 10.0 \\
\hline 24 & - & - & 0.0034 & 11,6 & 0.0262 & 10.9 \\
\hline 27 & 0.0319 & 11.7 & 0.0288 & 11.4 & - & - \\
\hline 32 & - & - & - & - & 0.028 & 13.7 \\
\hline 35 & 0.0317 & 11.7 & - & - & - & - \\
\hline 39 & - & - & - & - & 0.0279 & 12.4 \\
\hline 48 & - & - & 0.0287 & $11 \cdot 3$ & 0.0288 & 12.8 \\
\hline
\end{tabular}


Table 21

Drying dete for 1 insoed oil contnintin .025 rram cobnlt and 7 rrams carbon binck pex 100 grans o11. (Porcent 011, 93.2)

Eroohly made samlo 4 weeks artre 8 veeks acing

$$
\begin{aligned}
& \text { wt. anm10, } 0.2723 \mathrm{G} . \\
& \text { wt. oil, } 0.2540 \mathrm{G} .
\end{aligned}
$$

Wt. semole,0.2205 E. Wt. sample, 0.2321 E. it. 011, $0.2056 \mathrm{~g}$. oll, $0.2161 \mathrm{~g}$.

\begin{tabular}{|c|c|c|c|c|c|c|}
\hline 1 & 0.0000 & 0.0 & 0.0000 & 0.0 & 0.0000 & 0.0 \\
\hline 3 & 0.0000 & 0.0 & 0.0000 & 0.0 & 0.0004 & 0.2 \\
\hline 2.5 & 0.000 & 0.0 & 0.0000 & 0.0 & 0.006 & 0.2 \\
\hline 3 & 0.0000 & 0.0 & 0.0000 & 0.0 & 0.0006 & 0.2 \\
\hline 3.5 & 0.0000 & $0.0^{-}$ & 0.000 & 0.1 & 0.0008 & 0.2 \\
\hline 4 & 0.0000 & 0.0 & 0.0002 & 0.1 & 0.0006 & 0.2 \\
\hline 4.5 & 0.0000 & 0.0 & 0.0002 & 0.1 & 0.000 & 0.2 \\
\hline 5 & 0.0000 & 0.0 & 0.090 & 0.1 & .0006 & 0.2 \\
\hline 8.5 & $6.0000^{\circ}$ & 0.0 & - & - & 1.0007 & 0.3 \\
\hline 6 & 0.0002 & 0.1 & $0.000 ?$ & 0.1 & 0.0007 & 0.3 \\
\hline 7 & 0.0013 & 0.5 & 0.0002 & 0.1 & 0.07 & 0.3 \\
\hline 8 & 0.0020 & 1.0 & 0.0003 & 0.1 & 0,0007 & 0.3 \\
\hline 9 & 0.0062 & 2.3 & 0.0002 & 0.1 & C.con & 0.5 \\
\hline 10 & 0.0113 & $\Delta .2$ & 0.0004 & 0.2 & $0.4 ?$ & 0. \\
\hline 11.5 & 0.0183 & 0.7 & 0.0110 & 0.5 & 0.0007 & 0.3 \\
\hline 13 & 0.0231 & 8.5 & 0.0020 & 1.0 & 0.007 & 0.6 \\
\hline 15 & 0.067 & 9.9 & 0.0063 & 3.3 & 0.000 & 0.4 \\
\hline 17 & $0.029 B$ & 11.0 & 0.0120 & 6.2 & 0.001 & 0.8 \\
\hline 20 & 0.0305 & 11.2 & 0.040 & 11.7 & 0.018 & 0.9 \\
\hline 24 & - & - & 0.0274 & 13.3 & 0.0119 & 0.8 \\
\hline 27 & 0.0807 & 31.3 & 0.0278 & 13.5 & - & - \\
\hline 32 & - & - & - & - & 0.022 & 1.1 \\
\hline 30 & 0.0802 & 11.1 & - & - & - & - \\
\hline 30 & - & - & - & - & 0.0057 & 2.6 \\
\hline 48 & - & - & 0.0276 & 13.4 & 1.0167 & 7.2 \\
\hline
\end{tabular}






\section{FIG. 21 DRYING RATE OF LINSEED OIL}

\section{CONTAINING 0.025 GRAM COBALT PER 100 GRAMS OIL}

\section{A- O\% CARBON BL ACK}

B- 7 GRAMS CARBONBLACM PER 100 GRAMS OIL; FRESHLY MADE



$\sim$; $A G E D$ Q WEEHS
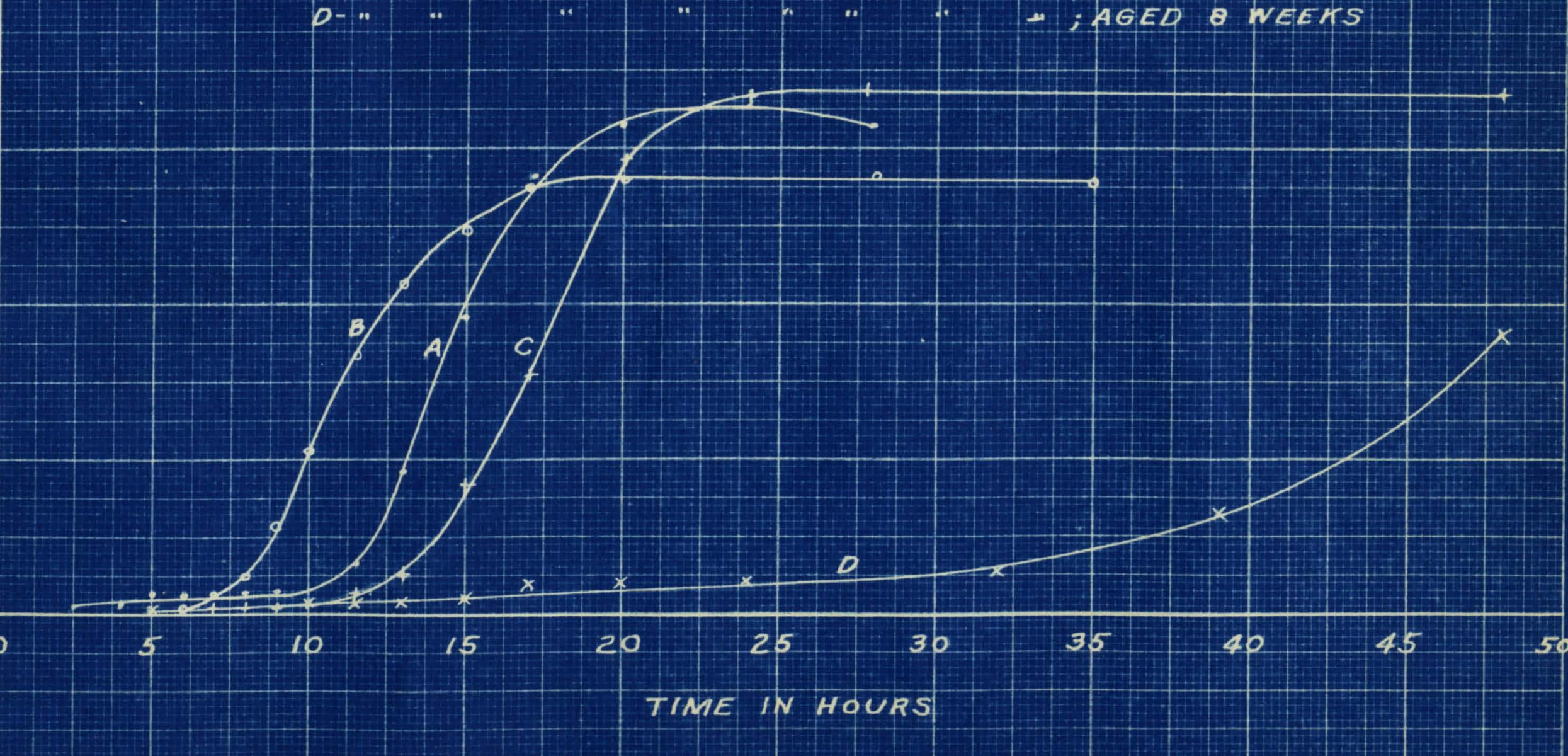
Table 22

Drying data for 1 insod oll contninin? 0.04 rem cobnlt and 3.5 erams cerbon black ner 100 erame o1l. (Percont oll, 16.?)

Froghly mado sam le 4 reeke aring 9 geeks arting

Wt. sarmle, $0.2406 \mathrm{~g}$. Wt. anple, $0.2237 \mathrm{~g}$. wt. samplo, $0.2577 \mathrm{C}$.

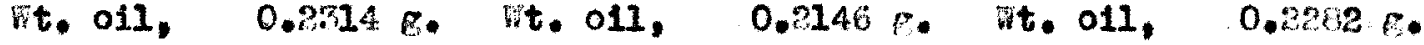



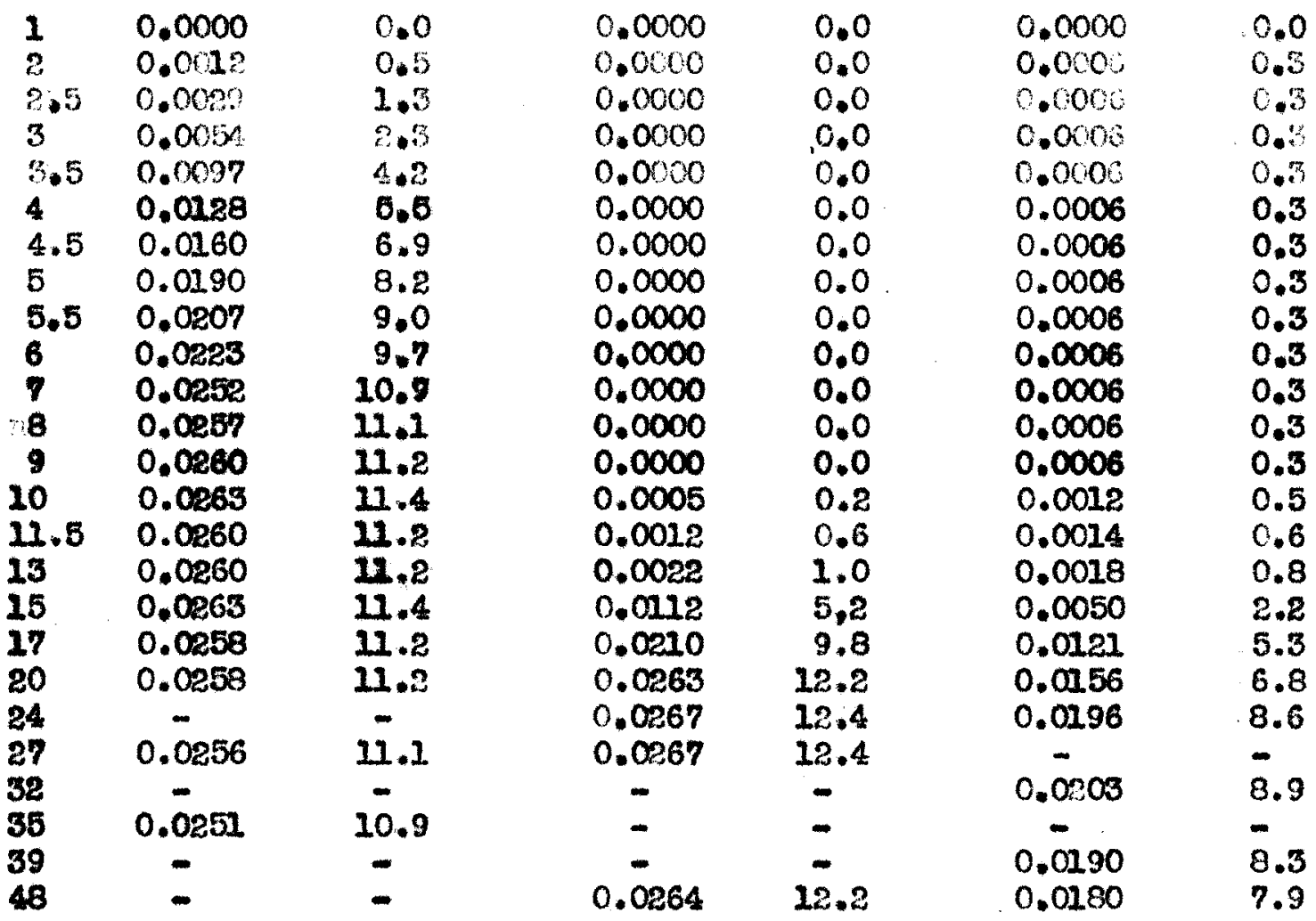


Tablo 23

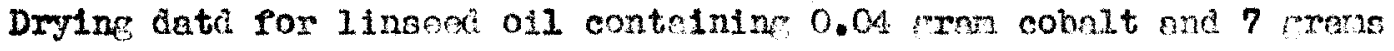
cerbon black ner 100 erems o11. (Porent o11, 93.0)

Fresily made sannle 4 woeke a ing 8 meeks eqing

Wt. sample, 0.2045 t. Wt. sample, 0.8355 g. Wt. sample, $0.2098 \mathrm{~g}$. Wt. oll, 0.1900 E. Wt. oll, 0.2188 E. Wt. o1l, 0.1950 E.

\begin{tabular}{|c|c|c|c|c|c|c|}
\hline $\begin{array}{l}\text { Tine, } \\
\text { hours }\end{array}$ & $\begin{array}{l}\text { Increase } \\
\text { In reiteht, } \\
\text { erans. }\end{array}$ & $\begin{array}{l}\text { of } \\
\text { incroase } \\
\text { in velent } \\
\text { of oll. }\end{array}$ & $\begin{array}{l}\text { Increase } \\
\text { In woleht, } \\
\text { Erone. }\end{array}$ & $\begin{array}{l}\text { increano } \\
\text { in woirht } \\
\text { of o1l. }\end{array}$ & $\begin{array}{l}\text { Incroase } \\
\text { in colcht, } \\
\text { prans. }\end{array}$ & $\begin{array}{l}\text { of } \\
\text { increase } \\
\text { in olfent } \\
\text { of otl. }\end{array}$ \\
\hline 1 & 0.0000 & 0.0 & 0.0000 & 0.0 & 0.0000 & 0.0 \\
\hline 2 & 0.0000 & 0.0 & 0.0000 & 0.0 & 0.0002 & 0.1 \\
\hline 2.5 & 0.0000 & 0.0 & 0.0000 & 0.0 & 0.0005 & 0.2 \\
\hline 3 & 0.0003 & 0.2 & 0.0000 & 0.0 & 0.0005 & 0.2 \\
\hline 3.0 & 0.0016 & 0.8 & 0.0000 & 0.0 & $0.000 \%$ & 0.9 \\
\hline 4 & 0.0030 & 1.6 & 0.0000 & 0.0 & 0.0003 & 0.2 \\
\hline 4.5 & 0.0056 & 5.0 & 0.0000 & 0.0 & $0.000 \mathrm{~s}$ & 0.2 \\
\hline 5 & 0.0080 & 4.2 & 0.0000 & 0.0 & $\because . O A$ & 0.2 \\
\hline 5.5 & 0.0105 & 6.5 & 0.0000 & 0.0 & 0.0008 & 0.4 \\
\hline 6 & 0.0188 & 7.0 & 0.0000 & 0.0 & 0.0008 & 0.4 \\
\hline 7 & 0.0180 & 9.5 & 0.0000 & 0.0 & 0.0008 & 0.4 \\
\hline 8 & 0.0200 & 10.5 & 0.0000 & 0.0 & 0.0008 & 0.4 \\
\hline 9 & 0.0216 & 11.4 & 0.0000 & 0.0 & 0.0008 & 0.4 \\
\hline 10 & 0.0226 & 11.9 & 0.0000 & 0.0 & 0.0000 & 0.4 \\
\hline 11.5 & 0.0896 & 11.9 & 0.0000 & 0.0 & 0.0008 & 0.4 \\
\hline 13 & 0.0230 & 10.1 & 0.0000 & 0.0 & 0.0008 & 0.4 \\
\hline 15 & 0.0230 & 12.1 & 0.0000 & 0.0 & 0.0012 & 0.6 \\
\hline 17 & 0.0226 & 11.9 & 0.0000 & 0.0 & 0.0013 & 0.7 \\
\hline 30 & 0.0223 & 11.7 & 0.0007 & $0 . ?$ & 0.0021 & 1.1 \\
\hline 24 & - & - & 0.0021 & 1.0 & 0.0030 & 1.2 \\
\hline 27 & 0.0223 & 11.7 & 0.0119 & 5.4 & - & - \\
\hline 32 & - & - & - & - & 0.0079 & $\Delta .0$ \\
\hline 35 & 0.0 .17 & 11.4 & - & - & - & - \\
\hline 39 & - & - & - & - & $0.0 \% 40$ & 12.3 \\
\hline 48 & - & - & 0.0271 & 12.4 & 0.0258 & 12.9 \\
\hline
\end{tabular}







The arying curves for linsed oll containing cobalt arior and carbon black were unllke the curvos for carbon black aemples with lead arier in most respects. The induction period of the freshly mado sample of oll and carbon black with cobalt drier vas mon greater than the Induction period of the unplemented oll except in the case of IInseed 011 containing 0.025 gram epbilt per 100 grans oll. This exception, however, is contradiotory to the econoral trond of the data. In the case of curves not showing an excoptionally long induotion pertod, the slope of the curves curing the constant drylar, rate period wes the seme; this correaponds to the behavior of carbon black earmples with loed arter. 
Table 24

Dryine dnta for linsed oll containing lead arler, ith no simat.

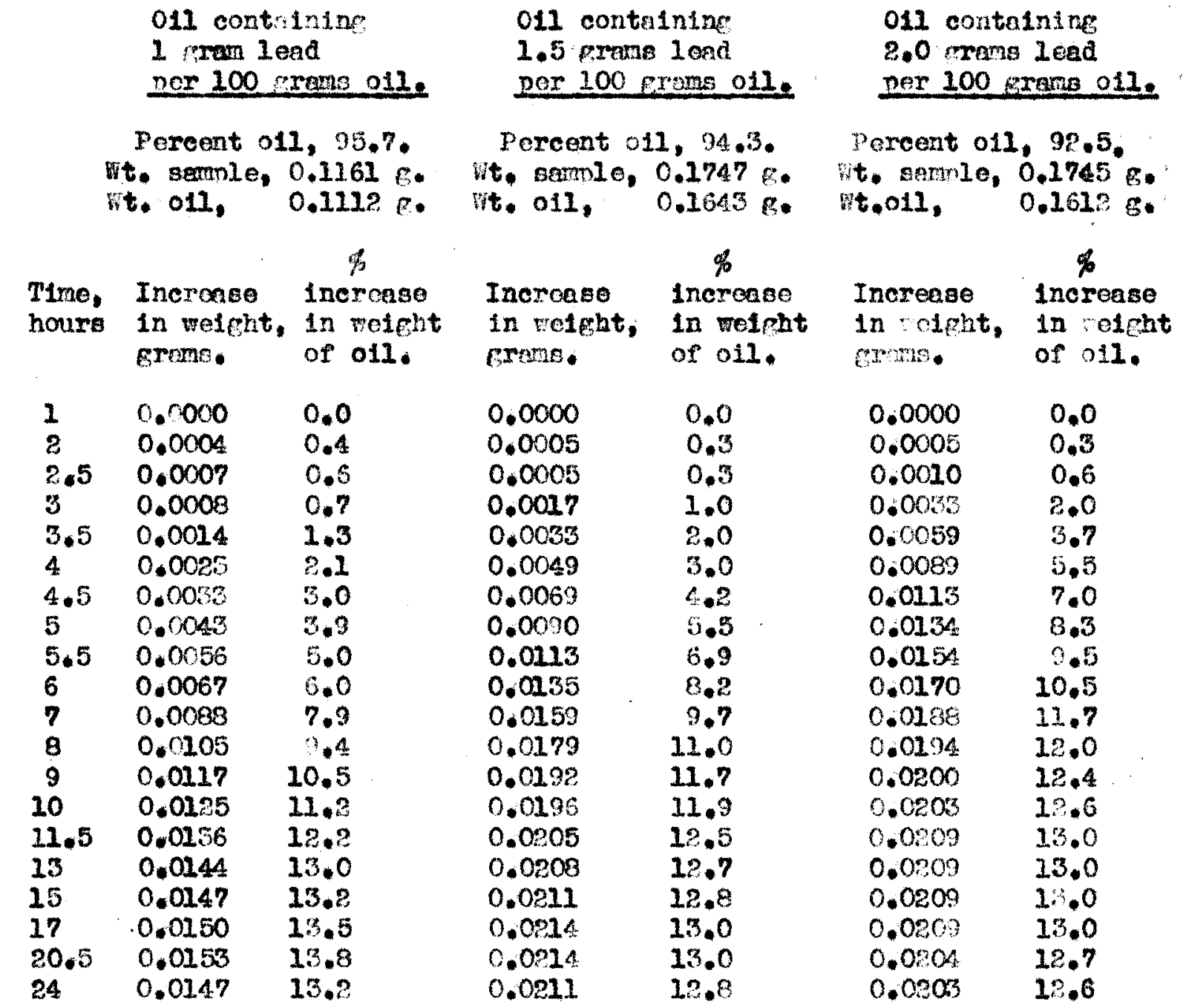


Toble 25

Drylne date for linseed oll containine cobalt ariar, with no vignent.

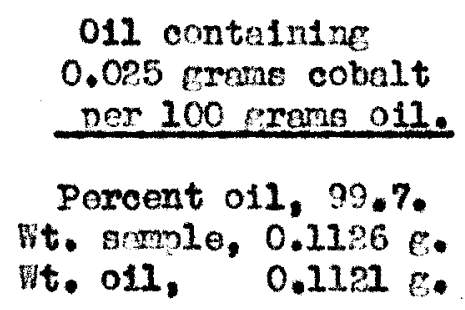

$\%$

Time,

hours

1

2

2.5

3

3.5

4

4.5

5

5.5

6

7

8

9

10

11.5

13

15

17

20

24

28

$\begin{array}{ll}\text { Increase } & \text { increase } \\ \text { in veight, } & \text { in veleht } \\ \text { grams. } & \text { of oll. }\end{array}$

0.0000

0.0000

0.0002

0.0008

0.0002

0.0002

0.0005

0.0007

0.0007

0.0007

0.0007

0.0007

0.0007

0.0007

0.0015

0.0041

0.0086

0.0127

0.0148

0.0147

0.014
0.0

0.0

0.2

0.2

0.2

0.2

0.4

0.6

0.6

0.6

0.6

0.6

0.6

0.6

1.3

$3 . ?$

7.7

11.3

12.7

13.1

12.6
011 contrinine

0.040 rrams cobalt

ner 100 groms oll.

vercont oil, 92.5.

Wt.samilo, $0.1836 \%$

Wt.011, $0.188 .6 \mathrm{~B}$.

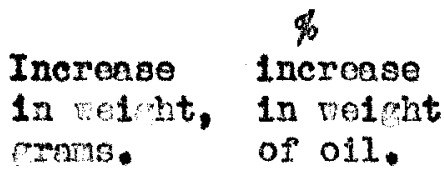

$0.0000 \cdot 0.0$

$0.0042 \quad 2.5$

$0.0069 \quad 4.1$

$0.0109 \quad 6.4$

$0.0140 \quad 3.3$

$0.0181 \quad 0.5$

$0.0185 \quad 10.9$

$0.0201 \quad 11.9$

$0.0213 \quad 12.6$

$0.0825 \quad 13.3$

$0.0 \% \% \quad 13.7$

$0.08 \% \quad 14.0$

$0.08 \% 36 \quad 14.0$

$0.0086 \quad 14.0$

$0.0256 \quad 14.0$

$0.02 \% 4 \quad 12.8$

$0.0851 \quad 12.6$

$0.0227 \quad 13.4$

$0.0219 \quad 12.9$

$0.0217 \quad 12.8$ 
68

CHAPTER V

STMLAFT 
The drying rates of linsead o1l, drier, and carbon plegent mixtures have been determined for freshly made amples, and for anples aged four and elght woeks.

The reaulte show that bone black and carbon black mixtures have the greatest 2085 in drying power ath inorease in age of the sample, whllo graphite and lemp black mixtures ahow the least 2088 of dxying power. In 1 inseed oll mixtures made with different concentrations of the eame plenent and with equal arier concentretion, 108 of arying power greater for the mixtures of higher plement concentration. In Iinseed oll mixture of different drier concentration, and with equal concentration of the same plgnent, the loss of aryine power $108 \mathrm{~s}$ for the mixtures of highor arier concentration. These reaule indicate that the black pignent reduces the erficiency of the drier with increase in age.

No correlation of this invegtigation $;$ the resulte of the Binney and Smith woxk (3) can be made, because only one type of carbon black was otudied in this Investigation while the Binney and Imt th pork Inaluded. only different types of carbon black.

The recults of this intestigation have the nrectical application that block 21 nseed oll paints, particularly those made with bone black and with carbon black, should be used as soon as poselble after manufacture for good arying resilts, 
Brencoraptx 


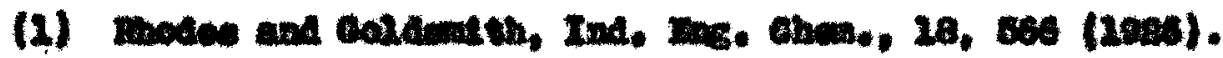

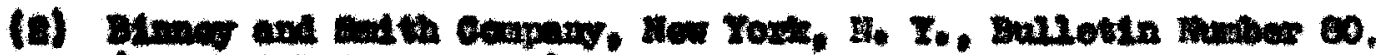

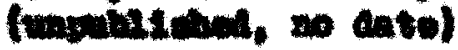

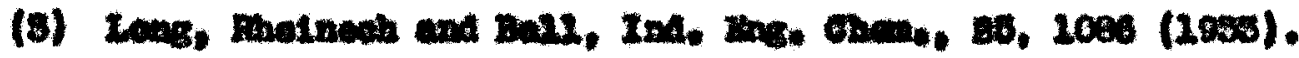

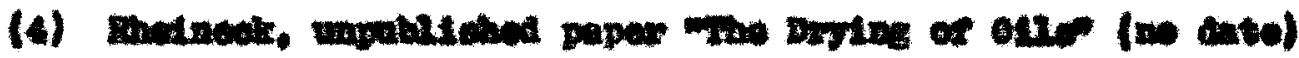


ACKOWLDGEMIII

The author wishes to express his appre-

eiation to the Loulsville 0il. Paint. and Varnish

club, whose scholarship made this investigution

possible, and to the Devoe and Faynolds Company and

the Binnoy and Snlth Company for furnishing wateriale. 